\title{
Manajemen Asuhan Keperawatan Jiwa Pada Ny. F Dengan Masalah Harga Diri Rendah Kronis: Studi Kasus
}

\author{
Inri Sihombing \\ Inrisihombing3006@gmail.com
}

\section{BAB 1 \\ PENDAHULUAN}

\subsection{Latar Belakang}

Skizofrenia merupakan bentuk psikosis fungsional paling berat dan menimbulkan disorganiasasi personalitas yang terbesar (Maramis, 2010 dalam Rahmadhani, 2021). Skizofrenia merupakan suatu gangguan jiwa berat yang bersifat kronis yang ditandai dengan ganggguan komunikasi, gangguan realitas, afek tidak wajar atau tumpul, gangguan fungsi kognitif serta mengalami kesulitan dalam melakukan aktivitas sehari-hari (Pardede, Keliat, 2019). Salah satu gejala negative dari skizofrenia adalah perubahan perubahan perilaku individu yang mana selalu menilai diri dan orang lain secara negative, atau menilai rendah terhadap kemampuan yang dimilikinya yang disebut harga diri rendah (Rokhimmah, 2020).

Skizofrenia ialah suatu gangguan jiwa berat yang bersifat kronis yang ditandai dengan ganggguan komunikasi, gangguan realitas, afek tidak wajar atau tumpul, gangguan fungsi kognitif serta mengalami kesulitan dalam melakukan aktivitas sehari-hari (Keliat, 2015). Gejala skizofrenia dapat mengalami perubahan semakin membaik atau semakin memburuk dalam kurun waktu tertentu, hal tersebut berdampak dengan hubungan pasien dengan dirinya sendiri serta orang yang dekat dengan penderita (Pardede, Keliat \& Wardani 2015).

Skizofrenia juga ditandai dengan gangguan pada proses pikir, dan juga disertai adanya ekspresi emosi yang tidak wajar (Sulistyono, dkk, 2018). Gejala skizofrenia dibagi menjadi dua kategori, yang pertama yaitu positif ditandai dengan adanya disorientasi 
pikiran, bicara dan perilaku yang tidak teratur. Salah satu jenis gangguan jiwa skizofrenia adalah skizofrenia paranoid. Secara klasik skizofrenia tipe paranoid ditandai terutama oleh adanya gangguan waham. Waham merupakan salah satu gangguan orientasi realitas. Gangguan orientasi realitas adalah ketidakmampuan klien menilai dan berespons pada realitas (Sofian, 2017).

Menurut WHO (2016), diperkirakan 450 juta orang diseluruh dunia mengalami gangguan jiwa, sekitar $10 \%$ orang dewasa akan mengalami gangguan jiwa saat ini dan $25 \%$ penduduk diperkirakan akan mengalami gangguan jiwa pada usia tertentu selama hidupnya. Gangguan jiwa mencapai $13 \%$ dari penyakit secara keseluruhan dan kemungkinan akan berkembang menjadi 25\% ditahun 2030. Prevalensi skizofrenia yang cukup tinggi bukan hanya di dunia tetapi di Indonesia juga mengalami hal yang sama. Penelitian Pardede, Keliat \& Wardani (2015) mendapatkan hasil kelompok skizofrenia juga menempati sebesar $83.3 \%$ klien di rumah sakit jiwa RSJ Daerah Provinsi Sumatera Utara Medan. Penelitian yang dilakukan Christenson, dkk. Di sebuah komunitas orang tua di San Francisco, mereka yang dinilai memiliki gangguan kejiwaan mengalami gejala kecurigaan sebanyak 17\% (Asis, 2018).

Harga diri yang rendah yang dialami seseorang selama lebih dari 3 bulan merupakan harga diri rendah situasional. Sedangkan jika harga diri rendah yang dialami seseorang lebih dari 6 bulan merupakan harga diri rendah kronik yang harus segera ditindak lanjuti. Dampak dari seseorang yang memiliki harga diri rendah akan berisiko menarik diri dari lingkungan sosial. Halusinasi, risiko perilaku kekerasan bahkan percobaan bunuh diri merupakan dampak dari harga diri rendah (Anggit, 2017). Gejala negatif yang dialami klien harga diri rendah kronis diantaranya afek datar, tidak memiliki kemauan, merasa tidak nyaman, dan menarik diri dari masyarakat. Gejala negatif pada klien harga diri rendah kronis juga tampak dari tidak mampu mengekspresikan perasaan, hilangnya spontanitas dan rasa ingin tahu, menurunnya motivasi, serta hilangnya kemampuan melakukan aktivitas sehari-hari (Widianti, 2017).

Penyakit skizofrenia harga diri rendah kronis seringkali kambuh atau berulang sehingga perlu diberikan terapi jangka lama yaitu dengan memberi asuhan keperawatan jiwa untuk mengontrol perilaku hilangnya rasa percaya diri dari klien harga diri rendah kronis dengan 
pemberian intervensi keperawatan jiwa pada klien harga diri rendah berfokus pada membina hubungan saling percaya, memberi kegiatan sesuai dengan kemampuan klien, meningkatkan kontak dengan orang lain, mendorong klien mengungkapkan pikiran dan perasaan serta membantu melihat prestasi, kemampuan dan harapan klien (Pardede, Keliat \& Wardani, 2018).

Berdasarkan survey yang dilakukan oleh penulis di Ruangan rawat Mawar Rumah Sakit Jiwa Prof. Dr. M. Ildrem. Didapatkan jumlah data pasien rawat inap sebayak 20 pasien dengan skizofrenia dengan masalah keperawatan gangguan persepsi sensori halusinasi dan harga diri rendah kronis. Subjek dalam pemberian asuhan keperawatan jiwa ialah Ny. F. Klien dijadikan sebagai subjek dikarenakan pasien masih merasa tidak dihargai, tidak berguna, merasa minder, dan malu. 
Berdasarkan Latar belakang penulis tertarik mengambil judul "Asuhan Keperawatan Jiwa Pada Ny. F Dengan Harga Diri Rendah Kronis Di Rumah Sakit Jiwa Prof. M Ildrem”

\subsection{Rumusan Masalah}

Berdasarkan latar belakang masalah tersebut maka dapat dirumuskan masalah sebagai berikut : bagaimana memberikan Asuhan Keperawatan Jiwa Pada Ny. F Dengan Harga Diri Rendah Kronis di Rumah Sakit Jiwa Prof. Dr. M. Ildrem.

\subsection{Tujuan Penulisan}

\subsubsection{Tujuan Umum}

Kelompok mampu memberikan asuhan keperawatan jiwa pada Ny. F Dengan Harga Diri Rendah Kronis Di Rumah Sakit Jiwa Prof. Dr. M. Ildrem.

\section{i. Tujuan Khusus}

1. Mahasiswa mampu melakukan pengkajian pada klien dengan Harga Diri Rendah Kronis.

2. Mahasiswa mampu menegakkan diagnosa atau masalah keperawatan pada $\mathrm{Ny}$. F dengan Harga Diri Rendah Kronis.

3. Mahasiswa mampu menetapkan intervensi keperawatan secara menyeluruh pada Ny. F dengan Harga Diri Rendah Kronis.

4. Mahasiswa mampu melakukan tindakan keperawatan yang nyata pada $\mathrm{Ny}$. F dengan Harga Diri Rendah Kronis.

5. Mahasiswa mampu mengevaluasi asuhan keperawatan pada Ny. F dengan Harga Diri Rendah Kronis.

6. Mahasiswa mampu mendokumentasikan asuhan keperawatan pada Ny. F dengan Harga Diri Rendah Kronis. 


\section{BAB 2 \\ TINJAUAN TEORITIS}

\subsection{Konsep Harga Diri Rendah Kronis}

\subsubsection{Definisi}

Harga diri rendah kronis adalah suatu perasaan dalam diri seseorang yang menganggap bahwa dirinya itu negatif (Irawati, 2019). Harga diri rendah adalah evaluasi diri yang negatif, berupa mengkritik diri sendiri, dimana seseorang memiliki fikiran negatif dan percaya bahwa mereka ditakdirkan untuk gagal (Rahayu, 2019). Harga diri rendah merupakan perasaan negatif terhadap dirinya sendiri, termasuk kehilangan kepercayaan diri, tidak berharga, tidak berguna, pesimis, tidak ada harapan dan putus asa (Purwasih, 2016).

Harga diri rendah kronik adalah evaluasi diri/perasaan negatif tentang dirinya sendiri atau kemampuan diri yang berlangsung minimal tiga bulan (NANDA-I, 2018 dalam Keliat, 2020). Harga diri rendah melibatkan evaluasi diri yang negatif dan berhubungan dengan perasaan yang lemah, tidak berdaya, putus asa, ketakutan, rentan, rapuh, tidak lengkap, tidak berharga, dan tidak memadai (Stuart, 2016). Harga diri rendah kronis merupakan salah satu masalah keperawatan skizofrenia, karena harga diri rendah merupakan gejala negative dari skizofrenia (Pardede, Keliat, 2020).

Harga diri rendah adalah perasaan negatif terhadap dirinya sendiri menyebabkan kehilangan rasa percaya diri, pesimis, dan tidak berharga di kehidupan (Atmojo, 2021). Harga diri rendah merupakan keadaan dimana individu mengalami evaluasi diri negatif tentang kemampuan dirinya. Sehingga dapat diambil kesimpulan bahwa harga diri rendah yaitu seseorang yang mengalami gangguan untuk menilai dirinya sendiri dan kemampuan yang dimilikinya, menyebabkan hilangnya rasa kepercayaan diri yang berlangsung dalam waktu yang lama.

\subsubsection{Faktor Penyebab Harga Diri Rendah Kronis}

Faktor yang mempengaruhi harga diri rendah kronis meliputi faktor Predisposisi dan faktor Presipitasi yaitu (Diana, 2020) : 
1. Faktor Predisposisi

a. Faktor yang mempengaruhi harga diri rendah meliputi penolakan dari orang tua, seperti tidak dikasih pujian, dan sikap orang tua yang terlalu mengekang, sehingga anak menjadi frustasi dan merasa tidak berguna lagi serta merasa rendah diri.

b. Faktor yang mempengaruhi harga diri rendah juga meliputi ideal diri seperti dituntut untuk selalu berhasil dantidak boleh berbuat salah, sehingga anak kehilangan rasa percaya diri.

2. Faktor Presipitasi

Faktor presipitasi ditimbulkan dari sumber internal dan eksternal misalnya ada salah satu anggota yang mengalami gangguan mental sehingga keluarga merasa malu dan rendah diri. Pengalaman traumatik juga dapat menimbulkan harga diri rendah seperti penganiayaan seksual, kecelakaan yang menyebabkan seseorang dirawat di rumah sakit dengan pemasangan alat bantu yang tidak nyaman baginya. Respon terhadap trauma umumnya akan mengubah arti trauma dan kopingnya menjadi represi dan denial.

\subsubsection{Tanda dan Gejala Harga Diri Rendah Kronis}

Manifestasi yang biasanya muncul pada klien dengan masalah harga diri rendah kronis, Menurut Keliat (2020) antara lain :

a. Mayor

\section{i. Subjektif}

1. Menilai diri dengan negatif/mengkritik diri

2. Merasa tidak berarti/tidak berharga

3. Merasa malu/minder

4. Merasa tidak mampu melakukan apapun

5. Meremehkan kemampuan yang dimiliki

6. Merasa tidak memiliki kelebihan

\section{ii. Objektif}

1. Berjalan menunduk

2. Postur tubuh menunduk

3. Kontak mata kurang

4. Lesu dan tidak bergairah

5. Berbicara pelan dan lirih 
6. Ekspresi muka datar

7. Pasif

b. Minor

i. Subjektif

1. Merasa sulit konsentrasi

2. Mengatakan sulit tidur

3. Mengungkapkan keputusasaan

4. Enggan mencoba hal baru

5. Menolak penilaian positif tentang diri sendiri

6. Melebih-lebihkan penilaian negatif tentang diri sendiri

ii. Objektif

1. Bergantung pada pendapat orang lain

2. Sulit membuat keputusan

3. Sering kali mencari penegasan

4. Menghindari orang lain

5. Lebih senang menyendiri

\subsubsection{Proses Terjadinya Harga Rendah Diri}

Harga Diri Rendah terjadi akibat harga diri rendah situasional yang tidak terselesaikan atau ketidakadaan feed back (umpan balik) yang positif dari lingkungan terhadap perilaku klien sebelumnya. Respon negatif dari lingkungan juga memiliki peran terhadap gangguan harga diri rendah kronis. Pada awalnya klien dihadapkan dengan stresor (krisis) dan berusaha untuk menyelesaikannya tetapi tidak tuntas. Ketidaktuntasan itu menimbulkan evaluasi diri bahwa ia tidak mampu atau gagal menjalankan peran dan fungsinya. Evaluasi diri yang negatif karena merasa gagal merupakan gangguan harga diri rendah situasional yang berlanjut menjadi harga diri rendah kronis akibat tidak adanya respon positif dari lingkungan pada klien (Safitri, 2020). Harga diri yang rendah yang dialami seseorang selama lebih dari 3 bulan merupakan harga diri rendah situasional. Sedangkan jika harga diri rendah yang dialami seseorang lebih dari 6 bulan merupakan harga diri rendah kronik yang harus segera ditindak lanjuti (Anggit, 2017).

\subsubsection{Rentang Respon Harga Diri Rendah Kronis}

Adapun rentang respon harga diri rendah kronis menurut (Dwi, 2020) 


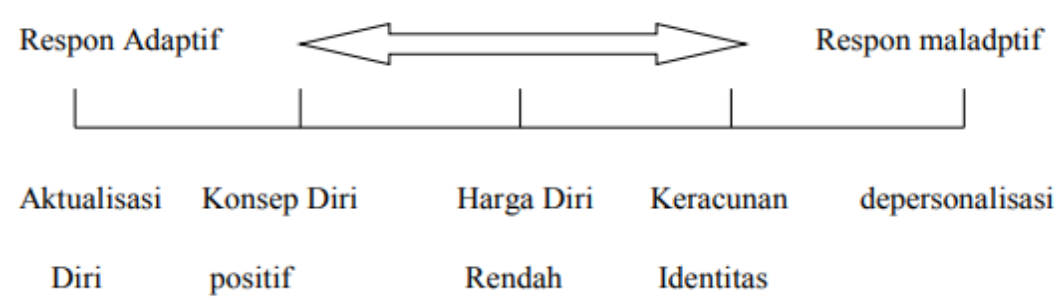

Keterangan :

1. Aktualisasi diri : Pernyataan konsep diri positif dengan pengalaman sukses.

2. Konsep diri positif : Mempunyai pengalaman positif dalam perwujudan dirinya.

3. Harga diri rendah : Perasaan yang negatif pada diri sendiri, hilangnya percaya diri, tidak berharga lagi, tidak berdaya, dan pesimis.

4. Keracunan identitas : Kegagalan seseorang untuk mengintegrasikan berbagai identifikasi masa anak-anak.

5. Dipersonalisasi : Perasaan sulit membedakan diri sendiri dan merasa tidak nyata dan asing

\subsubsection{Mekanisme Koping Harga Diri Rendah Kronis}

Seseorang dengan harga diri rendah kronis memiliki mekanisme koping jangka pendek dan jangka panjang. Jika mekanisme koping jangka pendek tidak memberikan hasil yang telah diharapkan individu, maka individu dapat mengembangkan mekanis koping jangka panjang (Dwi, 2020).

Mekanisme tersebut mencakup sebagai berikut :

1. Jangka Pendek

a. Aktivitas yang dilakukan untuk pelarian sementara yaitu : pemakaian obat-obatan, kerja keras, nonton tv secara terus menerus.

b. Aktivitas yang memberikan penggantian identitas bersifat sementara, misalnya ikut kelompok sosial, agama, dan politik).

c. Aktivitas yang memberikan dukungan bersifat sementara misalnya perlombaan.

2. Jangka Panjang

Penutupan identitas :

a. terlalu terburu-buru mengadopsi identitas yang disukai dari orang-orang yang berarti tanpa memperhatikan keinginan atau potensi diri sendiri. 
b. Identitas Negatif : asumsi identitas yang bertentangan dengan nilai-nilai dan harapan masyarakat.

\subsection{Konsep Asuhan Keperawatan Jiwa}

\subsubsection{Pengkajian Keperawatan}

Pengkajian merupakan pengambilan data yang dilakukan pertama kali oleh perawat setelah klien masuk. Pengkajian merupakan tahap awal dari proses keperawatan. Disini semua data dikumpulkan secara sistematis untuk menentukan status kesehatan klien saat ini. Pengkajian harus dilakukan secara komprehensif terkait dengan aspek biologis, psikologis, social maupun spiritual klien. Pengkajian keperawatan tidak sama dengan pengkajian medis. Pengkajian medis difokuskan pada keadaan patologis, sedangkan pengkajian keperawatan ditujukan pada respon klien terhadap masalah-masalah kesehatan yang berhubungan dengan pemenuhan kebutuhan dasar manusia. Misalnya dapatkah klien melakukan aktivitas sehari-hari, sehingga fokus pengkajian klien adalah respon klien yang nyata maupun potensial terhadap masalah-masalah aktifitas harian (Sitorus, 2019).

Menurut (Dwi, 2020) isi pengkajian keperawatan jiwa:

a. Identitas

Nama, umur, jenis kelamin, No MR, tanggal masuk RS, tangal pengkajian.

b. Alasan masuk

Tanyakan kepada klien dan keluarga apa alasan klien dibawa ke rumah sakit, Keluhan utama klien dengan harga diri rendah kronis biasanya merenung atau menyendiri serta mengkritik atau menyalahkan diri sendiri.

c. Faktor Predisposisi

a. Riwayat Kesehatan Dahulu

1) Adanya riwayat gangguan pada klien atau keluarga.

2) Adanya gangguan fisik atau penyakit termasuk gangguan pertumbuhan dan perkembangan.

b. Riwayat Psikososial

1) Pada klien harga diri rendah riwayat psikososial yang perlu diketahui adalah pernah atau tidak melakukan atau mengalami dan atau menyaksikan penganiayaan fisik, seksual, penolakan dari 
lingkungan, kekerasan dalam rumah tangga, aniaya, dan tindakan kriminal.

2) Merasakan pengalaman masa lalu lain yang tidak menyenangkan baik bio, psiko, sosio, kultural, maupun spiritual.

c. Riwayat Penyakit Keluarga Harga diri rendah kronis dapat disebabkan oleh keturunan. Oleh karena itu, pada riwayat penyakit keluarga harus dikaji apakah ada keluarga yang pernah mengalami gangguan jiwa.

d. Faktor presipitasi

Masalah khusus tentang harga diri rendah kronis disebabkan oleh setiap situasi yang dihadapi individu dan ia tak mampu menyelesaikan masalah yang di hadapi . Situasi atas stressor ini dapat mempengaruhi terjadinya harga diri rendah kronis.

e. Pemeriksaan fisik

Memeriksa tanda-tanda vital, tinggi badan, berat badan, dan tanyakan apakah ada keluhan fisik yang dirasakan klien.

f. Psikososial

a. Genogram

Perbuatan genogram minumal 3 generasi yang menggambarkan hubungan klien dengan keluarga, masalah yang terkait dengan komunikasi, pengambilan keputusan, pola asuh, pertumbuhan individu dan keluarga.

b. Konsep Diri

1) Gambaran Diri

Tanyakan persepsi klien terhadap tubuhnya,bagian tubuh yang disukai,reaksi klien terhadap bagian tubuh yang tidak disukai dan bagian yang disukai.

2) Identitas Diri

Kaji kepuasan klien terhadap jenis kelaminya, status sebelum dirawat di rumah sakit. Klien merasa tidak berdaya dan rendah diri sehingga tidak mempunyai status yang di banggakan atau di harapkan di keluarga ataupun masyarakat.

3) Fungsi peran

Biasanya klien mengalami penurunan produktifitas dan merasa tidak mampu dalam melaksanakan tugas. 
4) Ideal diri

Tanyakan harapan tubuh, posisi status, peran. Harapan klien terhadap lingkungan, dan harapan klien terhadap penyakitnya.

5) Harga Diri

Klien mengejek dan mengkritik dirinya sendiri, menurunkan martabat, menolak kemampuan yang dimiliki.

c. Hubungan Sosial

Tanyakan siapa orang terdekat dikehidupan klien tempat mengadu, berbicara, minta bantuin, atau dukungan. Serta tanyakan organisasi yang diikuti dalam kelompok/ masyarakat.

1) Klien tidak mempunyai orang yang di anggap sebagai tempat mengadu dan meminta dukungan.

2) Klien merasa berada di lingkungan yang mengancam.

3) Keluarga kurang memberikan penghargaan kepada klien.

4) Klien sulit berinteraksi.

d. Spritual

Nilai dan keyakinan, kegiatan ibadah/ menjalankan keyakinan, kepuasaan dalam menjalankan keyakinan.

1) Falsafah hidup Klien merasa perjalanan hidupnya penuh dengan ancaman, tujuan hidupnya biasanya jelas.

2) Konsep kebutuan dan praktek keagamaan Klien mengakui adanya Tuhan tapi tidak yakin terhadap Tuhan, putus asa karena tuhan tidak memberikan sesuai apa yang dia inginkan dan tidak mau menjalankan kegiatan agama.

g. Status Mental

a. Penampilan

Penampilan tidak rapi karena klien kurang minat untuk perawatan diri.

Kemunduran dalam tingkat kebersihan dan kerapian, bau badan karena tidak mandi merupakan salah satu tanda gangguan jiwa dengan harga diri rendah kronis.

b. Pembicaraan

Klien dengan frekuensi lambat, tertatah, volume suara rendah, sedikit berbicara inkoheren dan bloking. 
c. Aktivitas Motorik

Tegang, lambat, gelisah, dan terjadi penurunan aktivitas interaksin

d. Alam Perasan

Klien biasanya merasakan tidak mampu dan pandangan hidupnya selalu pesimis.

e. Afek emosi

Terkadang afek klien tampak tumpul, emosi klien berubah-ubah, kesepian, apatis, depresi atau sedih, dan cemas.

f. Interaksi selama wawancara

1) Tidak kooperatif, atau mudah tersinggung.

2) Kontak mata kurang: tidak mau menatap lawan bicara.

3) Defensif: selalu mempertahankan pendapat dan kebenaran dirinya.

g. Persepsi-sensori

Klien mengalami halusinasi dengar/lihat yang mengancam atau memberi perintah.

h. Proses berpikir

1) Arus Pikir:

a) Koheren: pembicaraan dapat dipahami dengan baik.

b) Inkoheren: kalimat tidak berbentuk, kata-kata sulit dipahami.

c) Tangensial: pembicaraan yang berbelit-belit tapi tidak sampai pada tujuan.

d) Flight of ideas: pembicaraan yang melompat dari satu topik ke topik lainnya masih ada hubungan yan tidak logis dan tidak sampai pada tujuan.

e) Bloking: pembicaraan terhenti tiba-tiba kemudian dilanjutkan kembali.

f) Neologisme: membentuk kata-kata baru yang tidak di pahami oleh umum.

g) Sosiasi bunyi: mengucapkan kata-kata yang mempunyai persamaan bunyi.

2) Isi Pikir: Merasa bersalah dan khawatir, menghukum atau menolak diri sendiri, mengejek dan mengkritik diri sendiri.

i. Tingkat kesadaran 
Biasanya klien tampak bingung dan kacau, stupor adalah gangguan motorik seperti kelakuan, gerakan berulang-ulang, anggota tubuh klien dalam sikap canggung yang dipertahankan dalam waktu lama tetapi pasein menyadari semua yang terjadi dilingkungan, sedasi yaitu klien mengatakan bahwa ia merasa melayang-layang antara sadar atau tidak sadar.

j. Memori

1) Daya ingat jangka panjang:mengingat kejadian masa lalu lebih dari satu bulan

2) Daya ingat jangka menengah:dapat mengingat kejadian yang terjadi 1 minggu terakhir.

3) Daya ingat jangka pendek:dapat mengingat kejadian yang terjadi saat ini.

k. Tingkat konsentrasi dan berhitung

1) Peratikan klien mudah berganti dari satu obyek ke obyek lain atau tidak.

2) Tidak mampu berkonsentrasi.

3) Tidak mampu berhitung.

1. Kemampuan penilaian mengambil keputusan

1) Ringan: dapat mengambil suatu keputusan yang sederhana dengan dibantu.

2) Bermakna: tidak mampu mengambil suatu keputusan walaupun sudah dibantu.

m. Daya tilik diri

Klien tidak menyadari bahwa dia mengalami gangguan jiwa.

\subsubsection{Diagnosa Keperawatan}

Perawat kesehatan jiwa menganalisis data pengkajian dalam menentukan diagnosis. Landasan untuk memberikan asuhan keperawatan jiwa adalah pengenalan dan mengidentifikasi pola respons terhadap masalah kesehatan jiwa yang actual dan pontensial (Yusuf, 2015) 


\subsubsection{Tindakan Keperawatan}

Pada situasi nyata sering pelaksanaan jauh berbeda dengan rencana, hal ini terjadi karena perawat belum terbiasa menggunakan rencana tertulis dalam melaksanakan tindakan keperawatan. Sebelum melaksanakan tindakan keperawatan yang sudah direncanakan, perawat perlu memvalidasi dengan singkat apakah rencana tindakan masih sesuai dan dibutuhkan klien sesuai dengan kondisinya (here and now). Perawat juga menilai diri sendiri, apakah kemampuan interpersonal, intelektual, tekhnikal sesuai dengan tindakan yang akan dilaksanakan, dinilai kembali apakah aman bagi klien. Setelah semuanya tidak ada hambatan maka tindakan keperawatan boleh dilaksanakan (Rokhimma, 2020).

\subsubsection{Evaluasi Keperawatan}

Evaluasi adalah proses yang berkelanjutan untuk menilai efek dari tindakan keperawatan pada klien. Evaluasi dilakukan terus menerus pada respon klien terhadap tindakan yang telah dilaksanakan, evaluasi dapat dibagi dua jenis yaitu: evaluasi proses atau formatif dilakukan selesai melaksanakan tindakan. Evaluasi hasil atau sumatif dilakukan dengan membandingkan respon klien pada tujuan umum dan tujuan khusus yang telah ditentukan. Evaluasi keperawatan yang diharapkan pada klien yang mendapatkan asuhan keperawatan halusinasi, klien mampu mengenali halusinasi, klien terlatih mengontrol halusinasi, klien mampu bercakap-cakap dengan orang lain, klien mampu beraktivitas secara terjadwal (Andri, 2019). 


\section{BAB 3 \\ TINJAUAN KASUS}

\subsection{Identitas Klien}

$\begin{array}{lll}\text { Inisial } & : & \text { Ny.F } \\ \text { Jenis kelamin } & : & \text { Perempuan } \\ \text { Umur } & : & 27 \text { Tahun } \\ \text { Agama } & : & \text { Islam } \\ \text { Status } & : & \text { Belum menikah } \\ \text { Tanggal pengkajian } & : & \text { 31 Januari 2022 } \\ \text { Informan } & : & \text { Klien dan buku status }\end{array}$

\subsection{Alasan Masuk Rumah Sakit Jiwa}

Klien masuk ke rumah sakit jiwa diantar oleh abang kandungnya dan abangnya mengatakan klien sering merasa dirinya tidak berguna lagi, klien mengatakan tidak mempunyai kemampuan lagi yang bisa dirinya lakukan, Berdasarkan informasi yang diperoleh dari buku status, klien ketika pertama kali masuk RSJ sempat tidak mau makan dan minum hanya termenung saja, dan ketika klien disuruh mandi klien hanya diam dan menangis saja.

Masalah Keperawatan : Harga Diri Rendah kronis

\subsection{Faktor Predisposisi}

Klien tidak pernah mengalami kejang. Tidak ada keluarga yang punya penyakit gangguan jiwa. Sebelumnya klien pernah mengalami gangguan jiwa dan di rawat di RSJ Prof. Dr. M. Ildrem pada tahun 2021, yang mengakibatkan klien menjadi gangguan jiwa ketika ayahnya meninggal dunia dan klien mengatakan pernah bersetubuh dengan kakek tirinya. Klien sering menarik diri, merasa dirinya tidak berguna lagi sehingga lebih menutup diri. Masalah keperawatan: Harga Diri Rendah Kronis

\subsection{Fisik}

Klien tidak memiliki keluhan fisik, saat dilakukan pemeriksaan tanda-tanda vital, didapatkan hasil TD : 120/80 mmHg ; $\mathrm{N}: 75 \mathrm{x} / \mathrm{i} ; \mathrm{S}: 37^{\circ} \mathrm{C}$; P : 20x/i. Klien memiliki tinggi badan $155 \mathrm{~cm}$ dan berat badan $60 \mathrm{Kg}$. 


\subsection{Psikososial}

\subsubsection{Genogram}

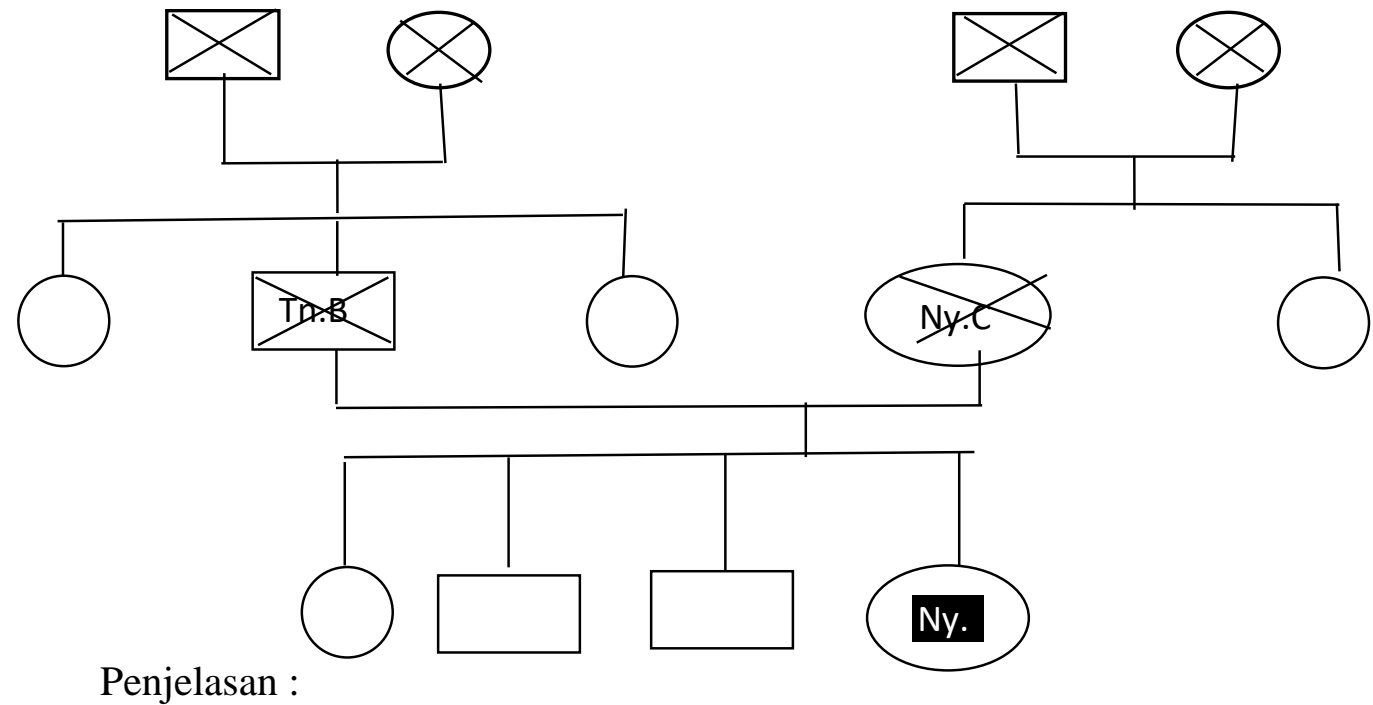

Klien anak ketiga dari 4 bersaudara, klien berinisial Ny.F , anak yatim piatu orangtuanya meninggal sekitar 15 tahun yg lalu.

Keterangan :

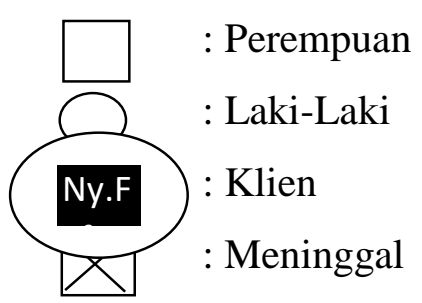

\subsubsection{Konsep Diri}

1. Gambaran diri : Klien menyukai seluruh tubuhnya dan tidak ada yang cacat

2. Identitas : Klien anak ke 2 dari 4 bersaudara, Klien lulusan SMA yang saat ini tidak memiliki pekerjaan

3. Peran : Klien tidak menjalankan peran dalam keluarga

4. Ideal diri $\quad$ Klien ingin cepat sembuh

5. Harga diri : Klien merasa tidak berarti lagi dalam menjalani kehidupannya

Masalah Keperawatan : Harga diri rendah kronis 


\subsubsection{Hubungan Sosial}

1. Peran serta dalam kegiatan kelompok/masyarakat : Klien bersifat apatis. Klien jarang mengikuti kegiatan kelompok di rumah sakit jiwa seperti beribadah, bergotong royong (memberikan halaman rumah, membakar sampah).

2. Hambatan dalam hungan dengan orang Lain : Penyakitnya yaitu gangguan jiwa. Klien hanya berbicara seperlunya saja. Ketika di tanya, klien hanya sebatas menjawab pertanyaan kita, lalu kebanyakan diam.

Masalah Keperawatan: Isolasi Sosial : Menarik diri

\subsubsection{Spiritual}

1. Nilai dan Keyakinan : Klien beragama Islam

2. Kegiatan Ibadah : Klien sering melakukan kegiatan

keagamaan di rumah sakit dengan motivasi.

\subsubsection{Status Mental}

1. Penampilan

Klien berpenampilan tidak rapi

2. Pembicaraan

Klien mampu menjawab pertanyaan dengan jelas tetapi tidak dapat cepat memahami pertanyaan yang diberikan.

3. Aktivitas Motorik

Klien dapat melakukan aktivitas dengan baik

4. Suasana perasaan

Klien merasa tidak dianggap ada lagi oleh keluarganya karena tidak pernah di jenguk selama di rawat di rumah sakit jiwa. Dan merasa minder dengan orang lain.

Masalah keperawatan : Harga Diri Rendah Kronis

5. Afek

Klien berespon dengan baik

6. Interaksi selama wawancara

Klien kooperatif, tidak ada kontak mata pada lawan bicara, sering menunduk dan tidak banyak bicara.

7. Persepsi

Klien mendengar suara-suara memanggil dirinya seperti suara ibunya. 
8. Proses Pikir

Klien mampu menjawab apa yang ditanya dengan baik.

9. Isi pikir

Klien dapat mengontrol isi pikirnya.

10. Tingkat kesadaran

Tingkat kesadaran composmentis klien mampu berorientasi orang, waktu dan tempat.

11. Memori

Klien mampu menceritakan kejadian di masa lalu.

12. Tingkat konsentrasi berhitung

Klien mampu berkonsentrasi dalam perhitungan sederhana tanpa bantuan orang lain.

13. Kemampuan penilaian

Klien dapat membedakan hal yang baik dan yang buruk.

14. Daya tilik diri

Klien tidak mengingkari penyakit yang diderita, klien mengetahui bahwa dia memiliki harga diri rendah, karena selalu merasa dirinya tidak ada gunanya lagi hidup di dunia ini.

\subsection{Mekanisme Koping}

Klien mengalami mekanisme koping adaptif yaitu klien dapat berbicara baik dengan orang lain.

\subsection{Masalah Psikososial dan Lingkungan}

Klien mengatakan sulit berteman dengan orang lain karena klien lebih banyak diam, klien sangat sulit untuk memulai pembicaraan dengan orang lain. Lebih sering termenung sendirian.

\subsection{Pengetahuan Kurang Tentang Gangguan Jiwa}

Klien tidak mengetahui tentang penyakit gangguan jiwa dan klien tahu obat apa yang diminum nya setiap hari yang diberikan oleh staf pegawai rumah sakit jiwa. 


\subsection{Analisa Data}

\begin{tabular}{|c|c|c|}
\hline No. & Identifikasi Data & Masalah Keperawatan \\
\hline 1. & $\begin{array}{ll}\text { DS : } & \\
\text { - } & \text { Klien mmengatakan merasa tidak } \\
& \text { dihargai dan klien merasa tidak } \\
& \text { berguna } \\
\text { - } & \text { Klien mengatakan merasa minder } \\
& \text { dan malu karena tidak bisa } \\
& \text { melakukan apapun dalam hidupnya. } \\
\text { - } & \text { Klien mengatakan merasa sedih } \\
& \text { karena di rawat di rumah sakit jiwa } \\
\text { - } & \text { Klien mengatakan hidupnya tidak } \\
& \text { berguna } \\
\text { - } & \text { Klien juga mengatakan tidak mampu } \\
& \text { dan merasa malu untuk melakukan } \\
& \text { sesuatu } \\
\text { DO : } & \text { Klien hanya sebatas menjawab } \\
\text { - } & \text { Klien tampak sedih } \\
\text { - } & \text { Suara klien menjadi pelan saat } \\
& \text { melakukan wawancara } \\
& \text { Kontak mata kurang } \\
& \end{array}$ & $\begin{array}{l}\text { Gangguan Konsep Diri : } \\
\text { Harga diri rendah kronis }\end{array}$ \\
\hline 2. & $\begin{array}{ll}\text { DS : } & \\
\text { - } & \text { Klien mengatakan sulit berteman } \\
& \text { dengan orang lain } \\
\text { - } & \text { Klien lebih banyak diam } \\
\text { - } & \text { Klien sangat sulit untuk memulai } \\
& \text { pembicaraan dengan orang lain }\end{array}$ & Isolasi Sosial \\
\hline
\end{tabular}




\begin{tabular}{|c|c|c|c|}
\hline & $\begin{array}{r}- \\
\text { DO : } \\
\text { - } \\
\text { - }\end{array}$ & $\begin{array}{l}\text { Kebih sering termenung sendirian } \\
\text { Klien tampak menarik diri } \\
\text { Klien tampak menolak melakukan } \\
\text { interaksi } \\
\text { Klien tampak tidak ada kontak mata } \\
\text { Klien tampak lesu } \\
\text { Klien tampak sendih }\end{array}$ & \\
\hline 3. & $\begin{array}{r}\text { DS : } \\
- \\
- \\
- \\
-\end{array}$ & $\begin{array}{l}\text { Klien mengatakan sering mendengar } \\
\text { suara - suara yang memanggil } \\
\text { namanya namun orangnya tidak } \\
\text { terlihat } \\
\text { Klien merasa takut dan gelisah jika } \\
\text { mendengar suara itu muncul } \\
\text { Klien sering mendengar suara itu } \\
\text { jika klien sendirian } \\
\text { Klien mengatakan merasa takut bila } \\
\text { suara-suara yang di dengar datang } \\
\text { secara tiba-tiba } \\
\text { Klien tampak menutup telinganya } \\
\text { saat suara itu datang memanggil } \\
\text { namanya } \\
\text { Klien tampak berbicara ngawur dan } \\
\text { senyum - senyum sendiri } \\
\text { Klien tampak gelisah } \\
\text { Klien tampak berbicara sendiri }\end{array}$ & $\begin{array}{c}\text { Gangguan Persepsi } \\
\text { Sensori : Halusinasi } \\
\text { Pendengaran }\end{array}$ \\
\hline
\end{tabular}

\subsection{Masalah Keperawatan}

1. Gangguan konsep diri : Harga diri rendah kronis

2. Isolasi sosial 
3. Gangguan persepsi sensori : Halusinasi pendengaran

\subsection{Pohon Masalah}

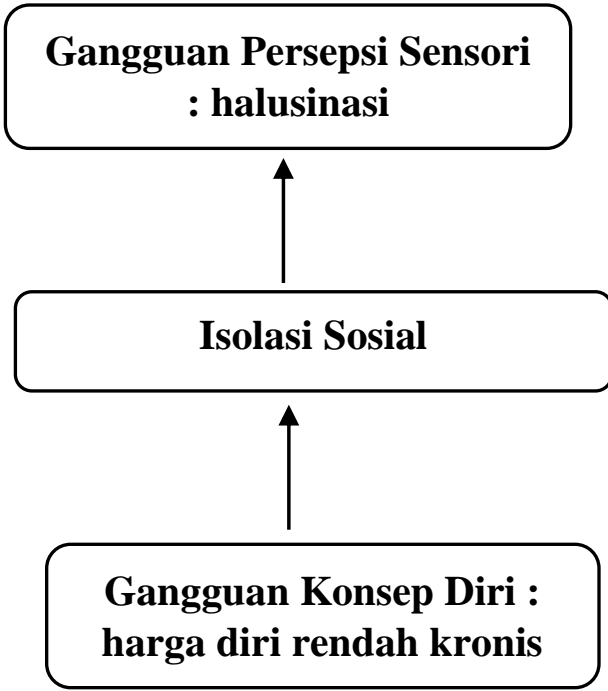

\subsection{Prioritas Diagnosa Keperawatan}

1. Gangguan konsep diri : Harga diri rendah kronis

2. Gangguan Persepsi Sensori : Halusinasi pendengaran

3. Isolasi Sosial

\subsection{Intervensi Keperawatan}

\begin{tabular}{|c|c|}
\hline $\begin{array}{c}\text { Diagnosa } \\
\text { Keperawatan }\end{array}$ & \multicolumn{1}{|c|}{ Intervensi } \\
rendah & $\begin{array}{l}\text { Sp 1: } \\
\text { Mengidentifikasi kemampuan dan aspek } \\
\text { positif yang dimiliki }\end{array}$ \\
& $\begin{array}{l}\text { Sp 2: } \\
\text { 1. Menilai kemampuan yang dapat } \\
\text { digunakan } \\
\text { 2. Menetapkan/memilih kegiatan sesuai } \\
\text { kemampuan } \\
\text { 3. Melatih kegiatan sesuai kemampuan } \\
\text { yang dipilih satu }\end{array}$ \\
\hline
\end{tabular}




\begin{tabular}{|c|c|}
\hline & $\begin{array}{l}\text { Sp 3: } \\
\text { Melatih kegiatan sesuai kemampuan yang } \\
\text { dipilih dua } \\
\text { Sp 4: } \\
\text { Melatih kegiatan sesuai kemampuan yang } \\
\text { dipilih tiga }\end{array}$ \\
\hline $\begin{array}{llll}\text { Gangguan } & \text { Persepsi } & \text { Sensori } & \text { : } \\
\text { Halusinasi } & & & \\
\end{array}$ & 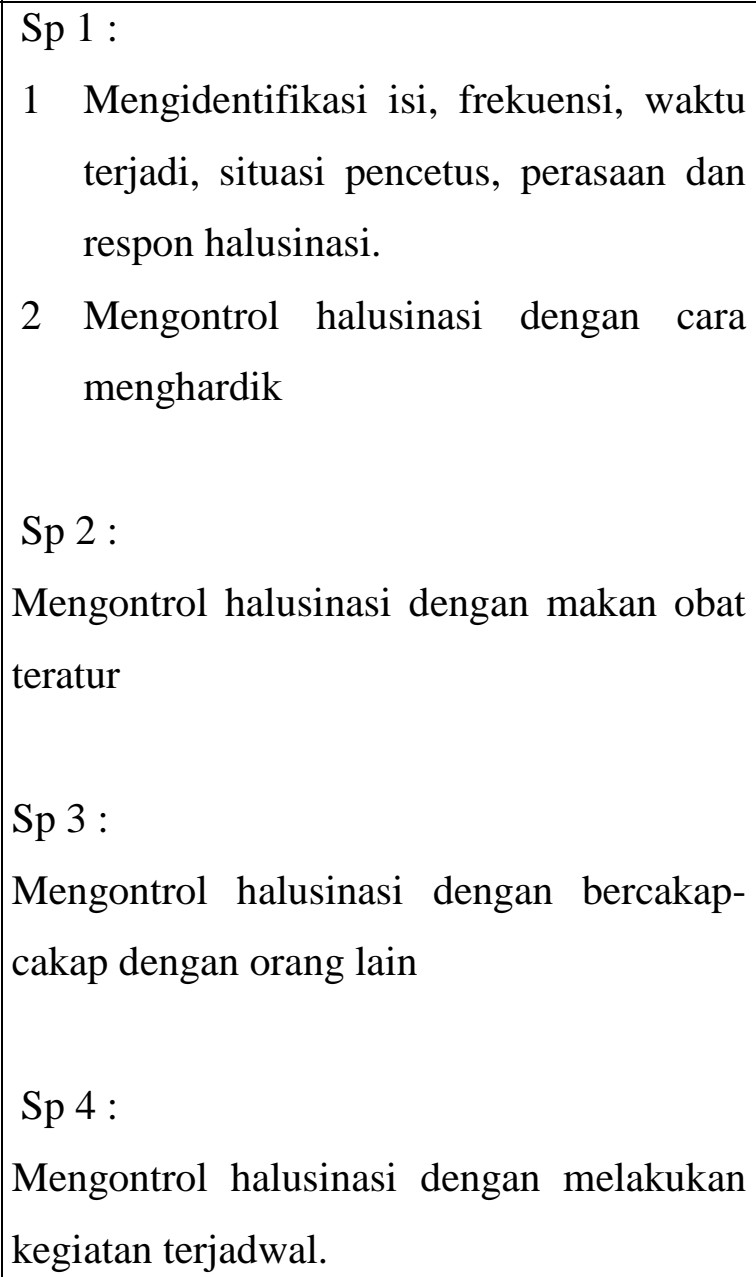 \\
\hline Isolasi Sosial & $\begin{array}{l}\text { Sp 1: } \\
\text { Menjelaskan keuntungan mempunyai teman } \\
\text { dan kerugian tidak mempunyai teman. } \\
\text { Sp } 2 \text { : } \\
\text { Latih klien berkenalan dengan dua orang } \\
\text { atau lebih }\end{array}$ \\
\hline
\end{tabular}




\begin{tabular}{|l|l|}
\hline Sp 3 : \\
Latih klien bercakap-cakap sambal \\
melakukan kegiatan harian \\
Sp 4: \\
Latih klienn berbicara social: meminta \\
sesuatu, berbelanja dan sebagainya
\end{tabular}

\subsection{Implementasi Keperawatan}

\begin{tabular}{|c|c|c|}
\hline $\begin{array}{c}\text { Hari / } \\
\text { Tanggal }\end{array}$ & Implementasi & Evaluasi \\
\hline $\begin{array}{l}\text { Rabu, } \\
02 \\
\text { Februari } \\
2022 . \\
10.30 \\
\text { Wib. }\end{array}$ & $\begin{array}{l}\text { 1. Data } \\
\text { Tanda dan gejala: } \\
\text { - Menilai diri negative/ mengkritik } \\
\text { diri } \\
\text { - Merasa malu karena masuk rumah } \\
\text { sakit jiwa } \\
\text { - Merasa tidak mampu menjadi ibu } \\
\text { yang baik karena takut anaknya } \\
\text { diejek anak orang gila. } \\
\text { - Kontak mata kurang } \\
\text { - Berbicara pelan dan lirih } \\
\text { Diagnosa Keperawatan } \\
\text { Gangguan konsep diri : Harga Diri } \\
\text { Rendah Kronis }\end{array}$ & $\begin{array}{ll}\text { O : } & \\
- & \text { Klien mampu } \\
& \text { mengikdentifikasi } \\
& \text { kemampuan dan aspek } \\
& \text { positif yang dimiliki klien } \\
& \text { dengan bantuan yaitu } \\
& \text { sholat, menyapu, menyuci } \\
& \text { piring. } \\
\text { A : } & \text { Harga diri rendah (+) } \\
\text { P : } & \\
\text { - } & \text { Latih klien merapikan } \\
& \text { tempat tidur 1x1 hari } \\
\text { - } & \text { Latih klien menyapu bawah } \\
& \text { tempat tidur 2x1 hari }\end{array}$ \\
\hline
\end{tabular}




\begin{tabular}{|c|c|c|}
\hline & $\begin{array}{l}\text { Mengidentifikasi kemampuan dan } \\
\text { aspek positif yang dimiliki klien } \\
\text { 4. RTL } \\
\text { Sp2: } \\
\text { - Menilai kemampuan yang dapat } \\
\text { digunakan } \\
\text { - Menetapkan/memilih kegiatan } \\
\text { sesuai kemampuan } \\
\text { - Latih kegiatan sesuai kemampuan } \\
\text { yang dipilih } 1\end{array}$ & \\
\hline $\begin{array}{l}\text { Kamis, } \\
03 \\
\text { Februari } \\
2022 . \\
10.30 \\
\text { Wib. }\end{array}$ & $\begin{array}{l}\text { 1. Data } \\
\text { Tanda dan gejala: } \\
\text { - Menilai diri negative/ mengkritik } \\
\text { diri } \\
\text { - Merasa malu karena masuk rumah } \\
\text { sakit jiwa } \\
\text { - Merasa tidak mampu menjadi ibu } \\
\text { yang baik karena takut anaknya } \\
\text { diejek anak orang gila. } \\
\text { - Kontak mata kurang } \\
\text { - Berbicara pelan dan lirih } \\
\text { 2. Diagnosa Keperawatan } \\
\text { Gangguan konsep diri : Harga Diri } \\
\text { Rendah Kronis } \\
\text { 3. Tindakan Keperawatan } \\
\text { Evaluasi } \\
\text { Sp2: } \\
\text { - Menilai kemampuan yang dapat }\end{array}$ & $\begin{array}{l}\text { S : Klien mengatakan senang dan } \\
\text { antusias mengikuti terapi } \\
\text { O : } \\
\text { - } \\
\text { Klien mampu mengenali } \\
\text { mengidentifikasi } \\
\text { kemampuan dan aspek } \\
\text { positif yang dimiliki klien. } \\
\text { - } \quad \text { Klien mampu melakukan } \\
\text { kegiatan sesuai kemampuan } \\
\text { yaitu sholat dengan } \\
\text { motivasi } \\
\text { A : } \\
\text { Parga diri rendah (+) } \\
\text { - }\end{array}$ \\
\hline
\end{tabular}




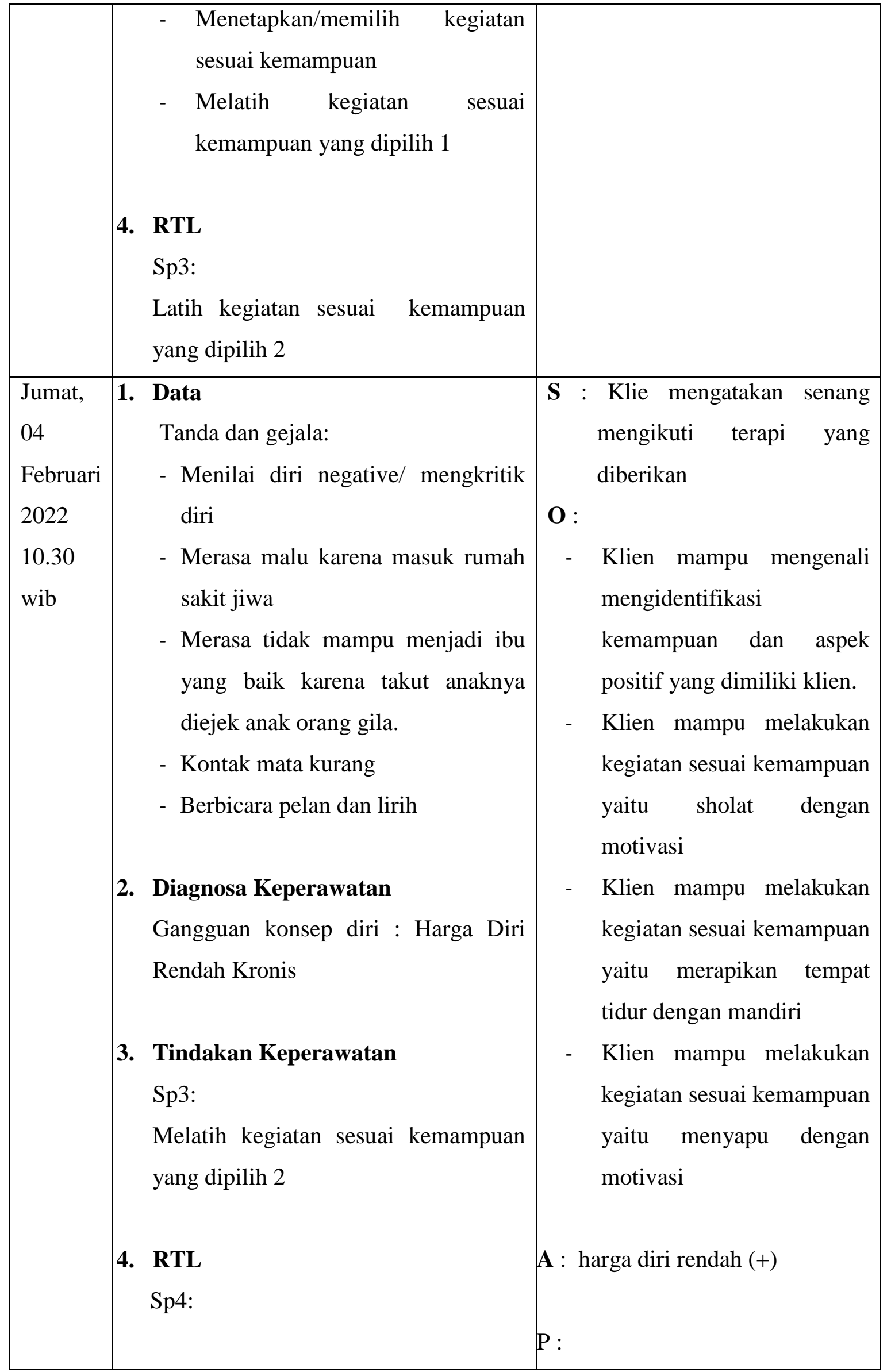




\begin{tabular}{|c|c|c|}
\hline & $\begin{array}{l}\text { Latih kegiatan sesuai kemampuan yang } \\
\text { dipilih } 3\end{array}$ & $\begin{array}{l}\text { Latih klien melakukan kegiatan } \\
\text { sesuai kemampuan: } \\
\text { - } \text { Sholat } 3 \times 1 \text { hari } \\
\text { - } \text { Merapikan tempat tidur } 2 \times 1 \\
\text { hari } \\
\text { - Menyapu ruangan } 2 \times 1 \text { hari }\end{array}$ \\
\hline $\begin{array}{l}\text { Sabtu, } \\
05 \\
\text { Februari } \\
2022 \\
14.00 \\
\text { wib }\end{array}$ & $\begin{array}{l}\text { 1. Data } \\
\text { Tanda dan gejala: } \\
\text { - Menilai diri negative/ mengkritik } \\
\text { diri } \\
\text { - Merasa malu karena masuk rumah } \\
\text { sakit jiwa } \\
\text { - } \text { Merasa tidak mampu menjadi ibu } \\
\text { yang baik karena takut anaknya } \\
\text { diejek anak orang gila. } \\
\text { - Kontak mata kurang } \\
\text { - Berbicara pelan dan lirih } \\
\text { 4. Diagnosa Keperawatan } \\
\text { Gangguan konsep diri : Harga Diri } \\
\text { Rendah Kronis } \\
\text { 3. Tindakan Keperawatan } \\
\text { Sp4: } \\
\text { Melatih kegiatan sesuai kemampuan } \\
\text { yang dipilih } 3 \\
\end{array}$ & $\begin{array}{l}\text { O : } \\
\text { - } \text { Klien mampu mengenali } \\
\text { mengidentifikasi } \\
\text { kemampuan dan aspek } \\
\text { positif yang dimiliki klien. } \\
\text { - } \text { Klien mampu melakukan } \\
\text { kegiatan sesuai kemampuan } \\
\text { yaitu sholat dengan } \\
\text { motivasi. } \\
\text { Klien mampu melakukan } \\
\text { kegiatan sesuai kemampuan } \\
\text { yaitu merapikan tempat } \\
\text { tidur dengan mandiri } \\
\text { Klien mampu melakukan } \\
\text { kegiatan sesuai kemampuan } \\
\text { yaitu menyapu dengan } \\
\text { mandiri } \\
\text { Klien mampu melakukan } \\
\text { kegiatan sesuai kemampuan } \\
\text { yaitu menyuci piring } \\
\text { sehabis makan dengan } \\
\text { mandiri }\end{array}$ \\
\hline
\end{tabular}




\begin{tabular}{|c|c|c|}
\hline & & 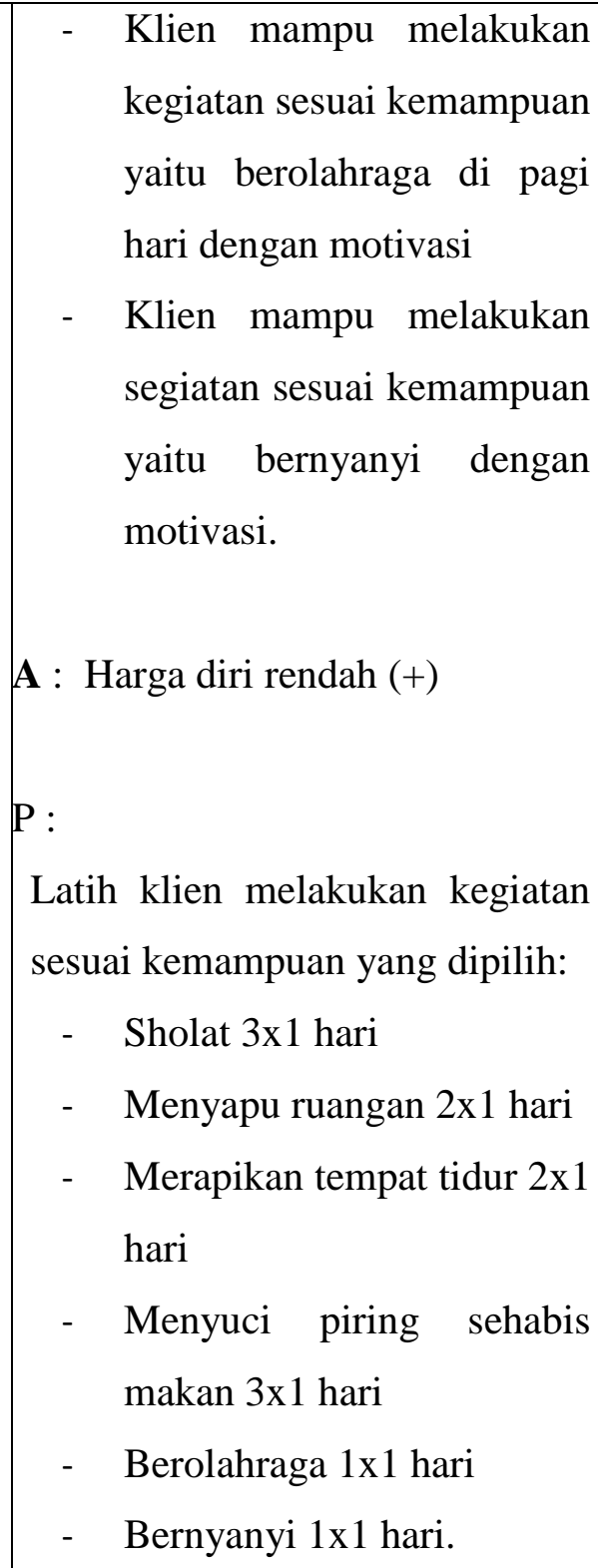 \\
\hline $\begin{array}{l}\text { Senin, } \\
07 \\
\text { Februari } \\
2022 \\
10.30 \\
\text { WIB. }\end{array}$ & $\begin{array}{l}\text { 1. Data } \\
\text { Tanda dan gejala: } \\
\text { - Menilai diri negative/ mengkritik } \\
\text { diri } \\
\text { - Merasa malu karena masuk rumah } \\
\text { sakit jiwa } \\
\text { - Merasa tidak mampu menjadi ibu } \\
\text { yang baik karena takut anaknya } \\
\text { diejek anak orang gila. } \\
\text { - Kontak mata kurang }\end{array}$ & 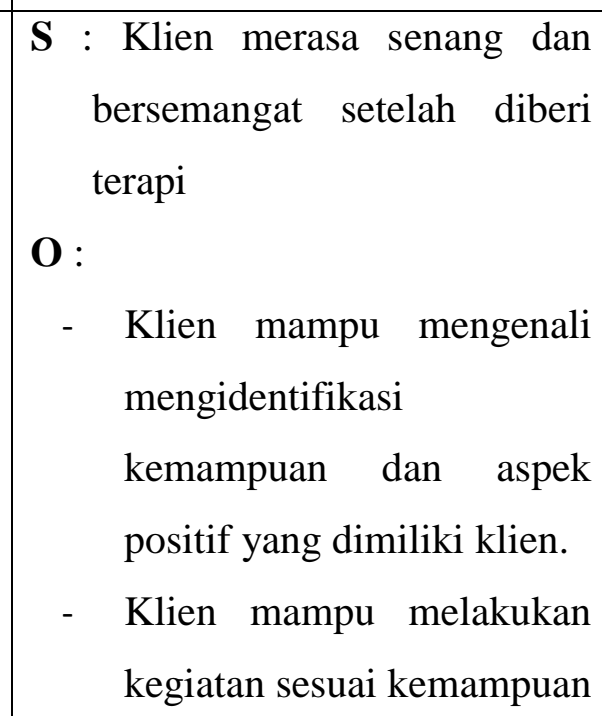 \\
\hline
\end{tabular}




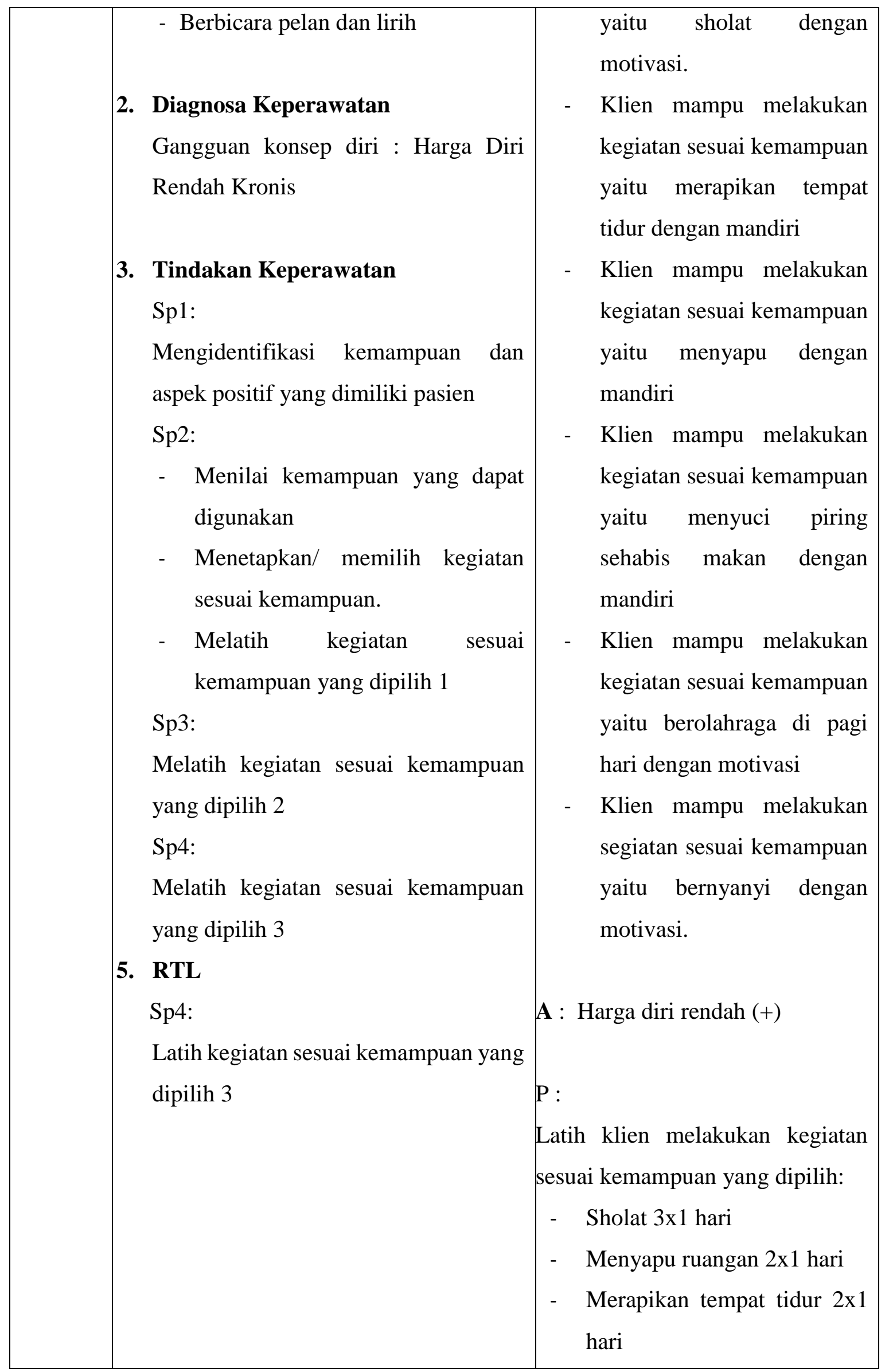




\begin{tabular}{|c|c|c|}
\hline & & $\begin{array}{ll}\text { - } & \text { Menyuci piring sehabis } \\
& \text { makan 3x1 hari } \\
\text { - } & \text { Berolahraga 1x1 hari } \\
\text { - } & \text { Bernyanyi 1x1 hari. }\end{array}$ \\
\hline $\begin{array}{l}\text { Selasa, } \\
08 \\
\text { Februari } \\
2022 \\
10.30 \\
\text { WIB. }\end{array}$ & 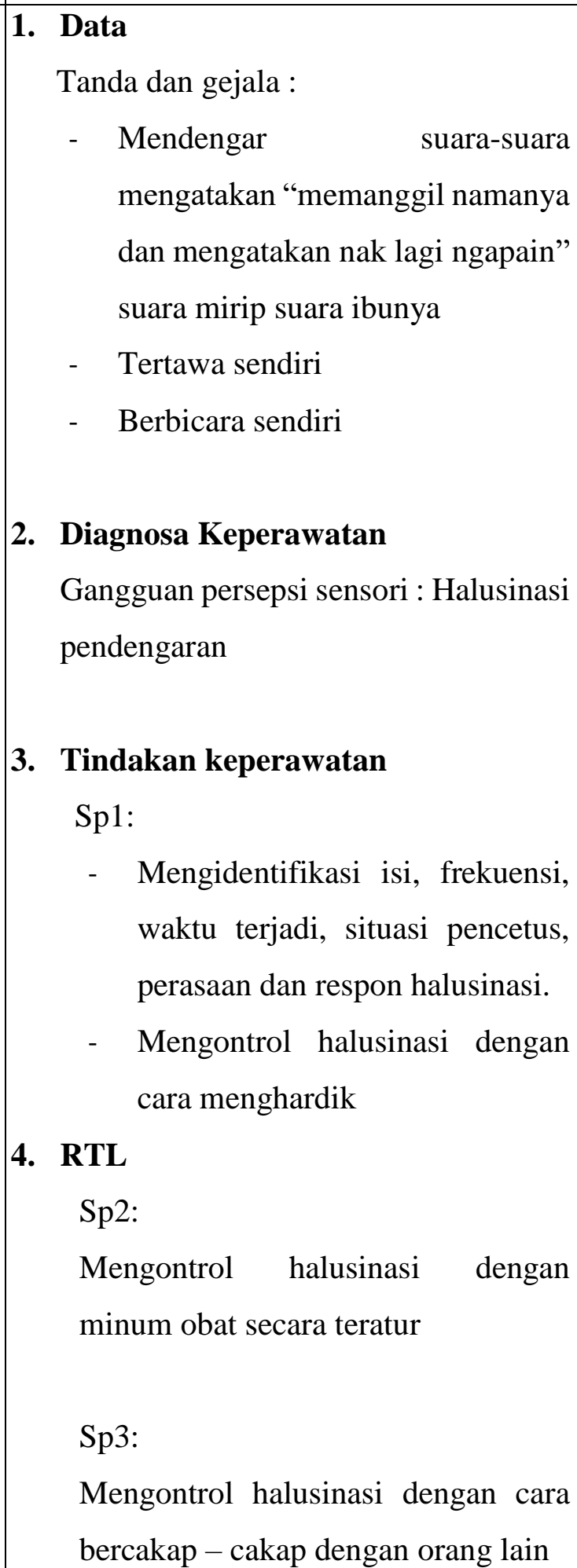 & 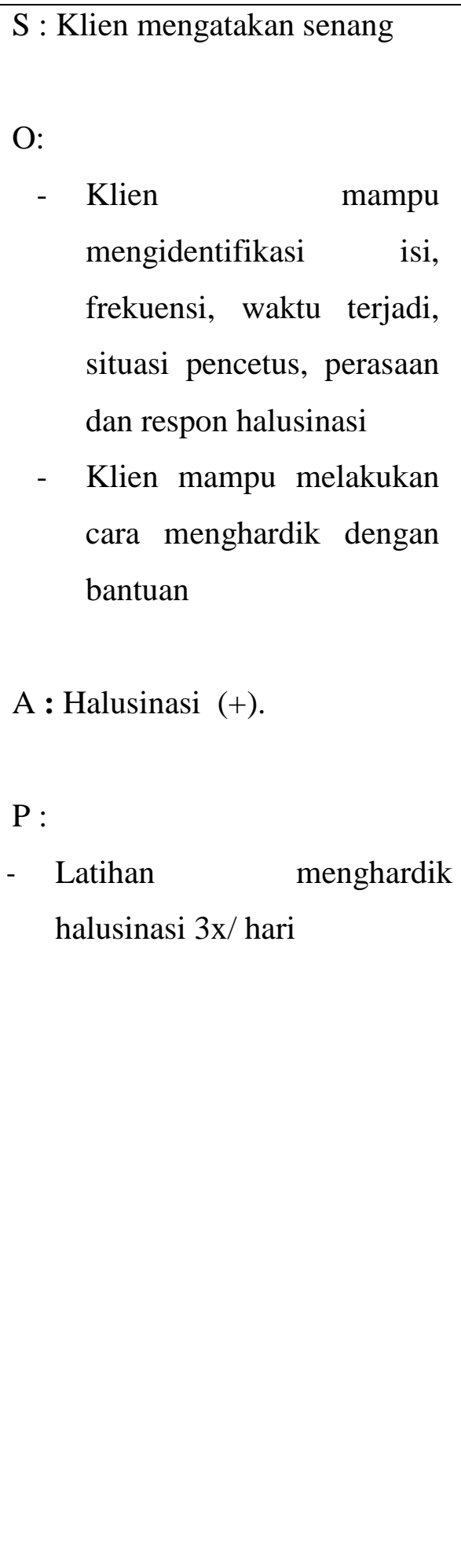 \\
\hline
\end{tabular}




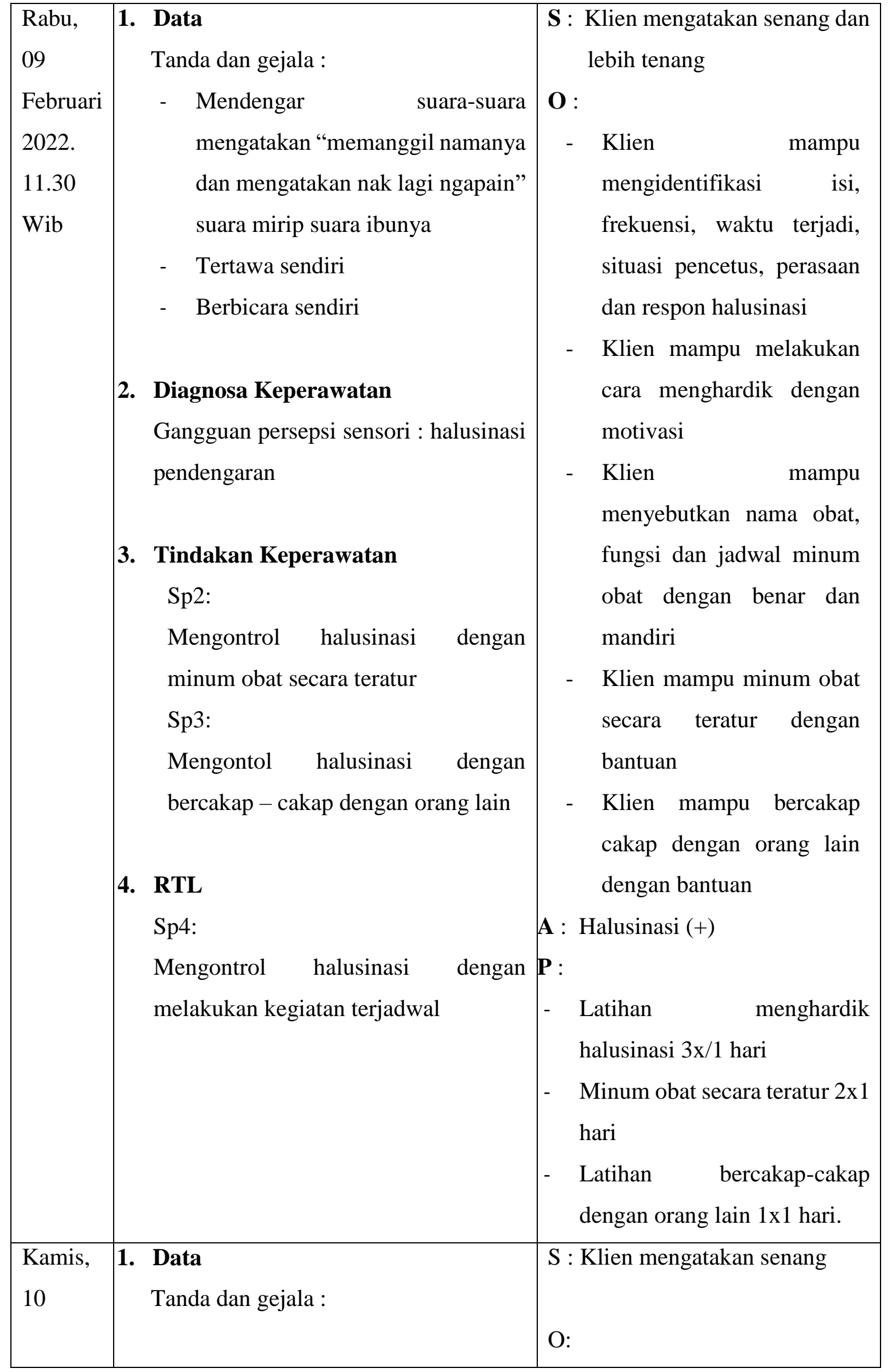




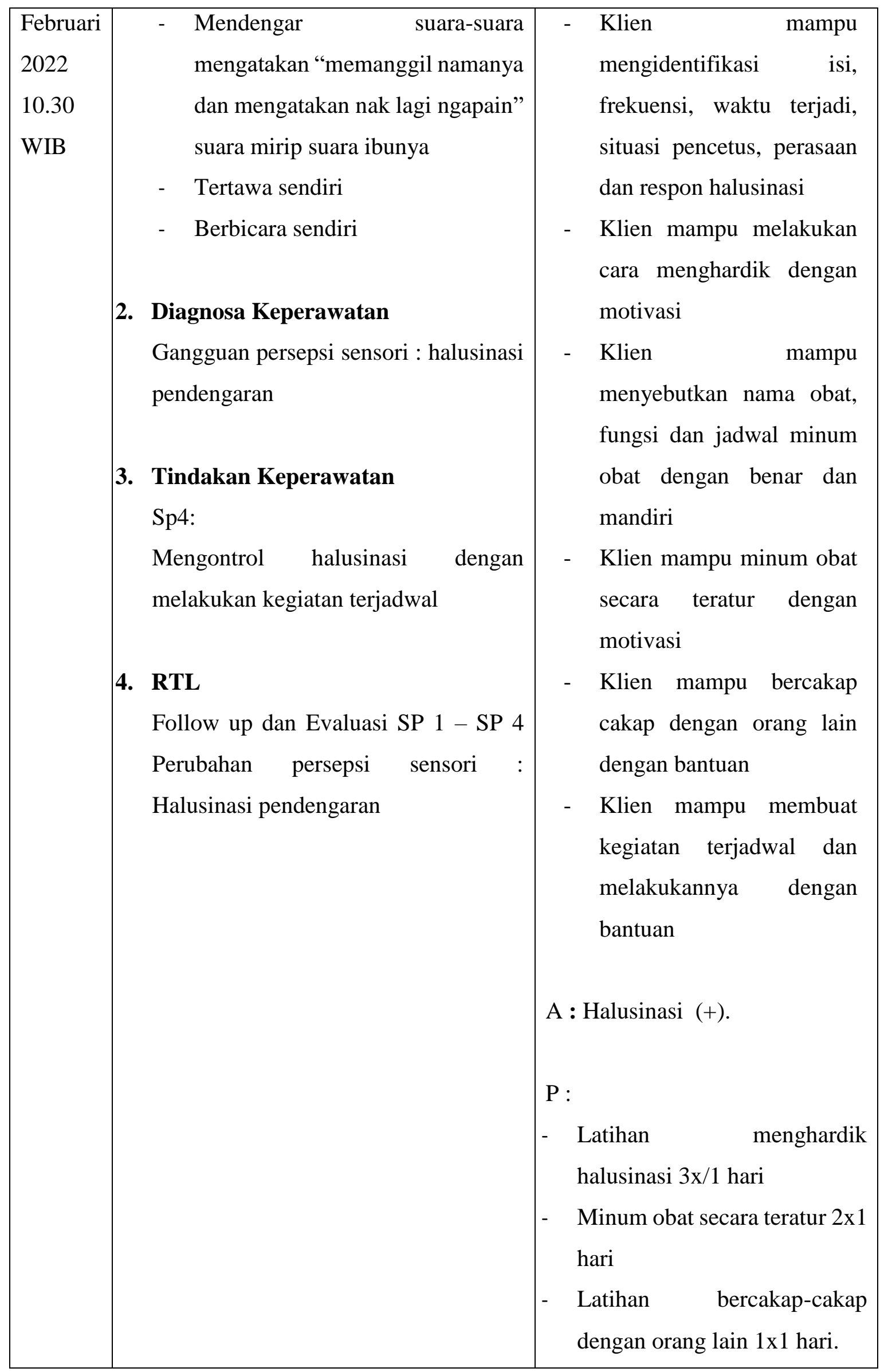




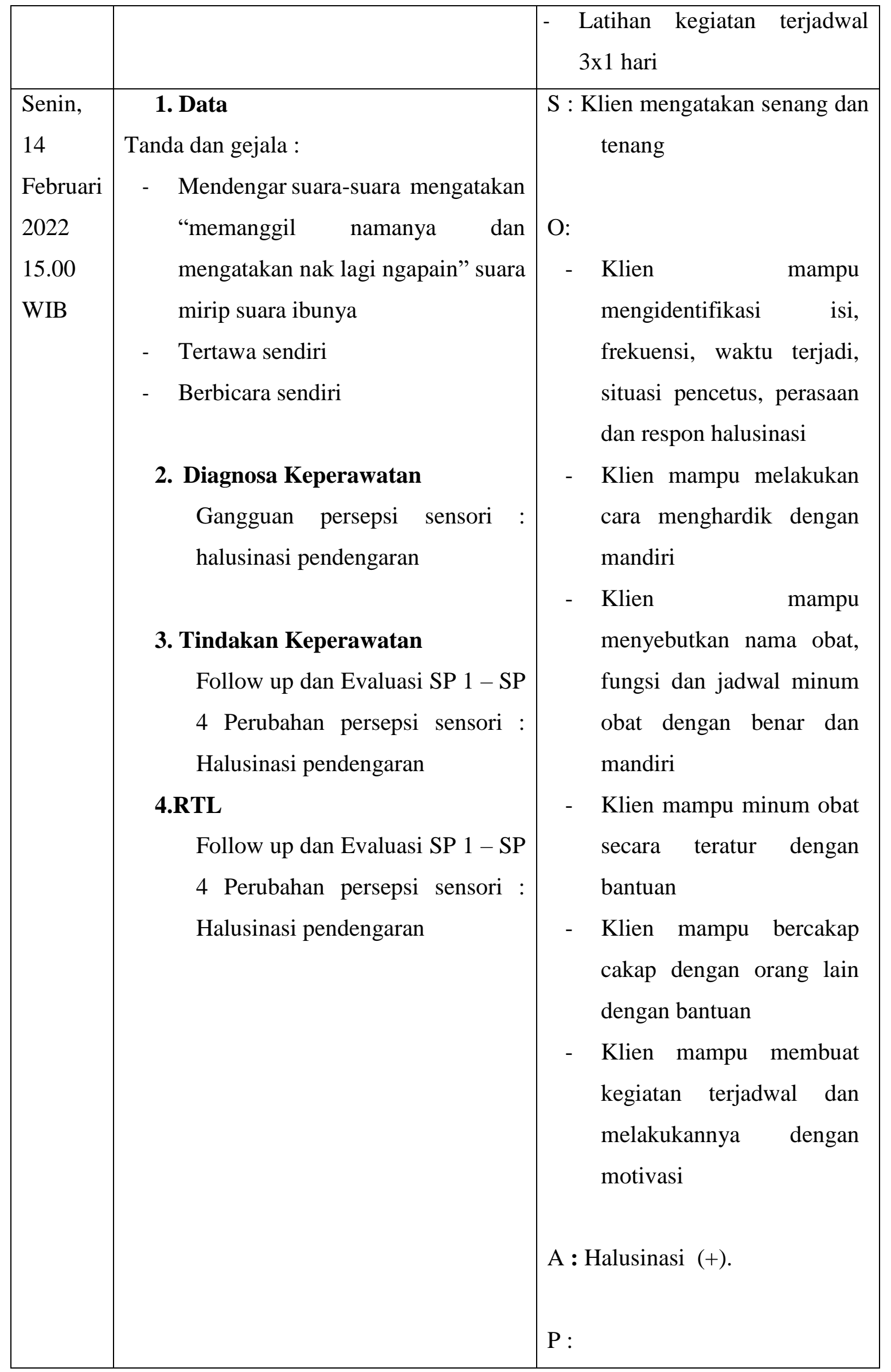




\begin{tabular}{|c|c|c|}
\hline & & 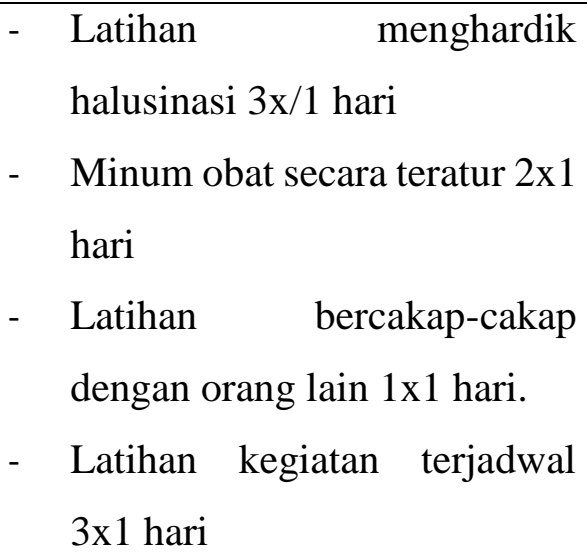 \\
\hline $\begin{array}{l}\text { Selasa, } \\
15 \\
\text { Februari } \\
2022 \\
15.30 \\
\text { WIB }\end{array}$ & $\begin{array}{l}\text { 1. Data } \\
\text { Tanda dan gejala : } \\
\text { - Menarik diri } \\
\text { - Menolak melakukan interaksi } \\
\text { - } \quad \text { Tidak bergairah dan lesu } \\
\text { - Merasa tidak diterima } \\
\text { 2. Diagnosa Keperawatan } \\
\text { Isolasi Sosial } \\
\text { 3. Tindakan Keperawatan } \\
\text { Sp1: } \\
\text { Menjelaskan Keuntungan mempunyai } \\
\text { teman dan kerugian tidak mempunyai } \\
\text { teman } \\
\text { Sp2: } \\
\text { Melatih klien berkenalan dengan dua } \\
\text { orang atau lebih } \\
\text { Latih klien bercakap-cakap sambil } \\
\text { melakukan kegiatan harian } \\
\text { Latih klien berbicara sosial: meminta } \\
\text { sesuatu, berbelanja, dll. } \\
\text { RT }\end{array}$ & $\begin{array}{l}\text { O: } \\
\text { - } \text { Klien mampu menjelaskan } \\
\text { keuntungan mempunyai } \\
\text { teman dan kerugian tidak } \\
\text { mempunyai teman dengan } \\
\text { bantuan } \\
\text { Klien mampu berkenalan } \\
\text { dengan } 2 \text { orang dengan } \\
\text { motivasi } \\
\text { A : Isolasi sosial (+). } \\
\text { P : } \\
\text { - Latihan berkenalan dengan } \\
\text { satu orang 1x1 hari } \\
\text { Latih klien berbicara dengan } \\
\text { teman di ruangan } 3 \times 1 \text { hari }\end{array}$ \\
\hline
\end{tabular}




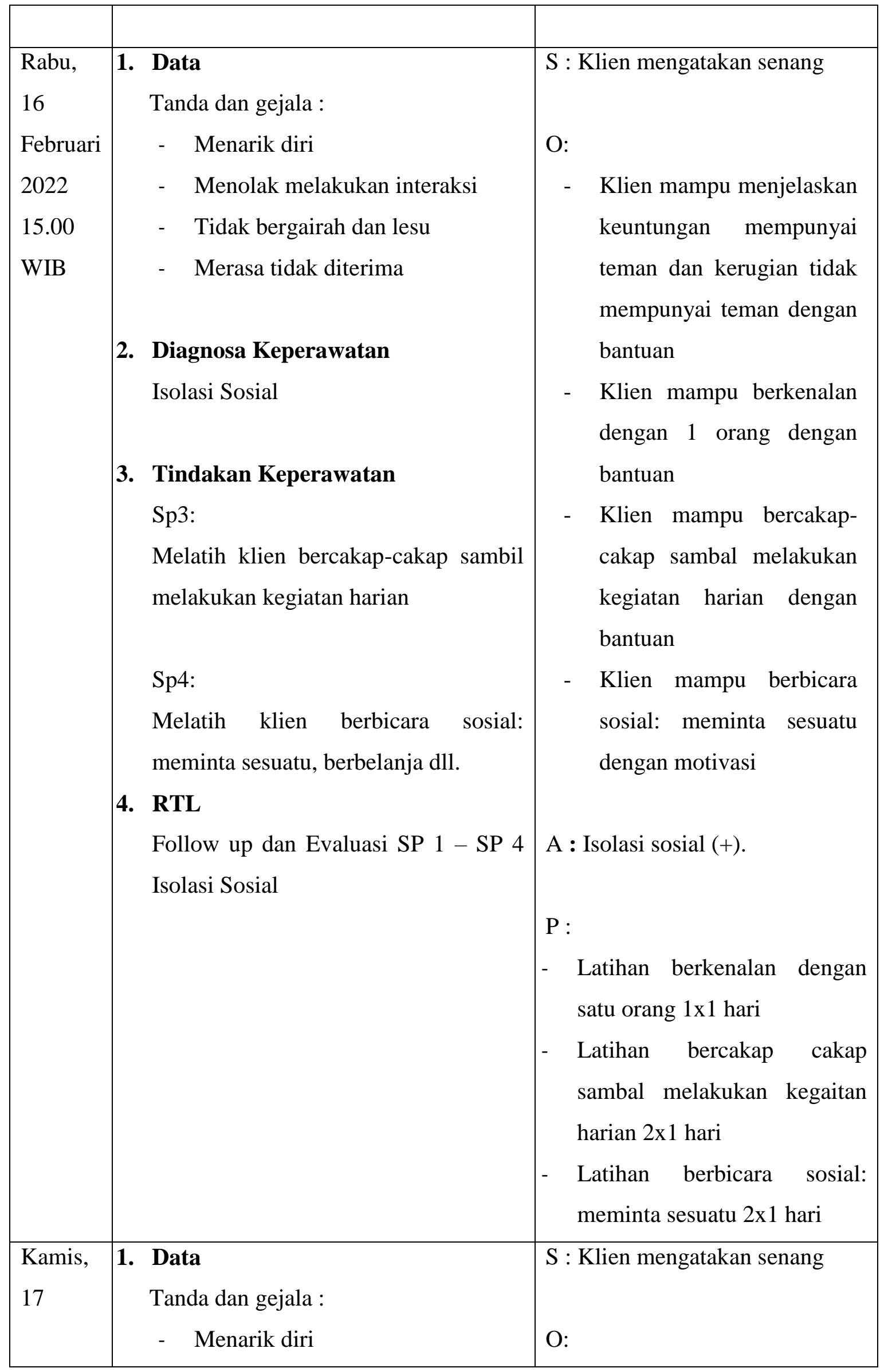




\begin{tabular}{|c|c|c|}
\hline $\begin{array}{l}\text { Februari } \\
2022 \\
16.00 \\
\text { WIB }\end{array}$ & $\begin{array}{l}\text { - } \text { Menolak melakukan interaksi } \\
\text { - } \quad \text { Tidak bergairah dan lesu } \\
\text { - } \quad \text { Merasa tidak diterima } \\
\text { 2. Diagnosa Keperawatan } \\
\text { Isolasi Sosial } \\
\text { 3. Tindakan Keperawatan } \\
\text { Evaluasi SP 1 - SP } 4 \text { Isolasi Sosial } \\
\text { 4. RTL } \\
\text { Sp4: } \\
\text { Latih kegiatan sesuai kemampuan yang } \\
\text { dipilih } 3\end{array}$ & 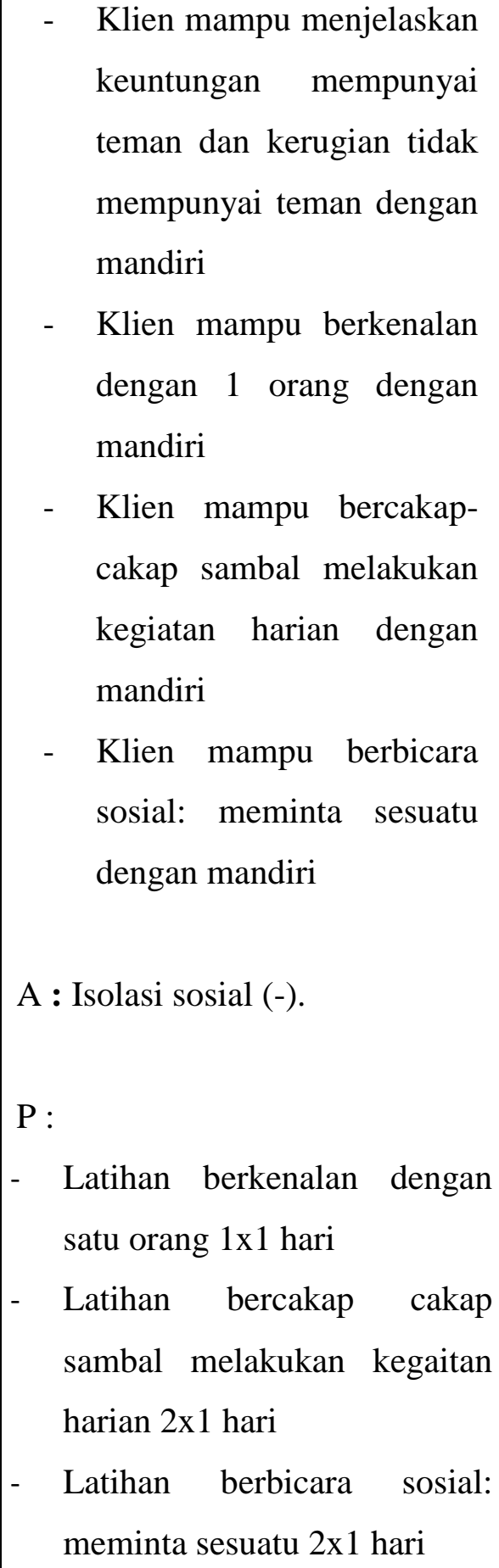 \\
\hline
\end{tabular}




\section{BAB 4 \\ PEMBAHASAN}

Setelah penulis melaksanakan asuhan keperawatan kepada Ny. F dengan Harga Diri Rendah Kronis di Rumah Sakit Jiwa Prof. M Ildrem, maka penulis pada BAB ini akan membahas kesenjangan antara teoritis dengan tinjauan kasus. Pembahasan dimulai melalui tahapan proses keperawatan yaitu pengkajian, diagnosa keparawatan, perencanaan, pelaksanaan dan evaluasi.

\subsection{Tahap Pengkajian}

Selama pengkajian dilakukan pengumpulan data dari beberapa sumber, yaitu dari pasien dan tenaga kesehatan di rumah sakit jiwa. Penulis mendapat sedikit kesulitan dalam menyimpulkan data karena keluarga pasien tidak pernah mengunjungi pasien di rumah sakit jiwa. Maka penulis melakukan pendekatan kepada pasien melalui komunikasi teraupetik yang lebih terbuka membantu klien untuk memecahkan perasaannya dan juga melakukan observasi kepada pasien. Adapun upaya tersebut yaitu:

1. Melakukan pendekatan dan membina hubungan saling percaya diri pada klien agar klien lebih terbuka dan lebih percaya dengan menggunakan perasaan.

2. Mengadakan pengkajian klien dengan wawancara

3. Mengadakan pengkajian bertanya kepada pegawai rumah sakit jiwa yang ada di ruangan.

Dalam pengkajian ini, penulis tidak menemukan kesenjangan karena ditemukan hal sama seperti diteori: Mengkritik diri sendiri, perasaan tidak mampu, pandangan hidup yang pesimis, penurunan produktivitas, penolakan terhadap kemampuan diri, malu terhadap diri sendiri, bicara ngawur, suka menyendiri, kontak mata kurang (Pardede, 2019).

\subsection{Tahap perencanaan}

Perencanaan dalam proses keperawatan lebih dikenal dengan rencana asuhan keperawatan yang merupakan tahap selanjutnya setelah pangkajian dan penentuan diagnosa keperawatan. Pada tahap perencanaan penulis hanya

menyusun rencana tindakan keperawatan sesuai dengan pohon masalah keperawatan yaitu : Gangguan Konsep Diri : Harga diri rendah kronis

Pada tahap ini antara tinjauan teoritis dan tinjauan kasus tidak ada kesenjangan sehingga penulis dapat melaksanakan tindakan seoptimal mungkin dan didukung dengan tersedianya sarana ruangan perawat yang baik dan adanya bimbingan dan petunjuk dari 
petugas kesehatan dari rumah sakit jiwa yang diberikan kepada penulis. Secara teoritis digunakan cara strategi pertemuan sesuai dengan diagnosa keperawatan yang muncul saat pengkajian. Adapun upaya yang dilakukan penulis yaitu :

Gangguan Konsep Diri : Harga diri rendah kronis

1. Harga Diri Rendah Kronis

1. Mengidentifikasi kemampuan dan aspek positif yang dimiliki pasien

a. Menilai kemampuan yang dapat digunakan

b. Menetapkan atau memilih kegiatan sesuai kemampuan

c. Melatih kegiatan sesuai kemampuan yang dipilih 1

2. Melatih kegiatan sesuai kemampuan yang dipilih 2

3. Melatih kegiatan sesuai kemampuan yang dipilih 3

4. Mengevalusi jadwal kegiatan harian pasien.

2. Isolasi Sosial

1. Melatih klien berkenalan dengan dua orang atau lebih

2. Melatih klien bercakap cakap dengan orang lain

3. Latih bercakap-cakap sambil melakukan kegiatan harian

4. Melatih berbicara social : meminta sesuatu, berbelanja dan sebagainya

3. Halusinasi

a. Identifikasi isi, frekuensi, waktu terjadi, situasi pencetus, dan respon terhadap halusinasi

b. Mengontrol halusinasi dengan cara menghardik

c. Mengontrol Halusinasi dengan cara minum obat secara teratur

d. Mengontrol halusinasi dengan cara bercakap - cakap dengan orang lain

e. Mengontrol halusinasi dengan cara melakukan aktifitas terjadwal

\subsection{Tahap Implementasi}

Pada tahap implementasi mahasiswa hanya mengatasi masalah keperawatan dengan diagnosa keperawatan Gangguan Konsep Diri : Harga diri rendah kronis. Pada diagnosa keperawatan Gangguan Konsep Diri : Harga diri rendah kronis dilakukan strategi pertemuan yaitu mengidentifikasi kemampuan dan aspek positif yang dimiliki pasien, menilai kemampuan yang dapat digunakan menetapkan/ memilih kegiatan sesuai kemampuan "melatih kegiatan sesuai kemampuan yang dipilih 1", melatih kegiatan sesuai 
kemampuan yang dpilih 2, dan melatih kegiatan sesuai kemampuan yang di pilih 3 (Pardede, Keliat, \& Yulia, 2015).

\subsection{Tahap evaluasi}

Menurut Damayanti (2017) tinjauan kasus evaluasi yang dihasilkan adalah :

1. Pasien mempercayai perawat sebagai terapis

2. Pasien dapat mengidentifikasi kemampuan dan aspek positif yang dimiliki

3. Pasien mampu menilai kemampuan yang dapat digunakan

4. Pasien mampu menetapkan/ memilih kegiatan sesuai kemampuan "melatih kegiatan sesuai kemampuan yang dipilih 1 "

5. Pasien dapat melatih kegiatan sesuai kemampuan yang dpilih 2

6. Pasien dapat melatih kegiatan sesuai kemampuan yang di pilih 3 


\section{BAB 5 \\ PENUTUP}

\subsection{Kesimpulan}

Setelah menguraikan tentang proses keperawatan pada Ny.F dan disimpulkan bahwa klien dapat beroirentasi secara realita, dan mengatasi harga diri rendah dengan terapi yang di ajarkan oleh mahasiwa. Dimana klien dapat melakukan terapi generalis yang telah diajarkan oleh mahasiswa. Maka dapat diambil keputusan sebagai berikut Pengkajian yang dilaksanakan tidak banyak berbeda dengan pengkajian teoritis maupun penulis tidak mendapat kesulitan dalam pengkajian klien.

1) Pengkajian yang dilakukan tidak banyak berbeda dengan pengkajian teoritis dan penulis tidak mendapat kesulitan dalam pengkajian yang dilakukan

2) Dalam mengatasi masalah yang dihadapi klien, mahasiswa mapu Menyusun tindakan keperawatan sesuai dengan teoritis yang ada.

3) Dalam pelaksanaan tindakan keperawatan disesuaikan dengan perencanaan dan dapat dilaksanakan walaupun belum sepenuhnya dapat terlaksana.

4) Pada tahap evaluasi masalah yang dihadapi klien tidak teratasi semua sesuai dengan masalah klien.

\subsection{Saran}

1. Bagi Mahasiswa

Hendaknya mahasiswa/i dapat melakukan asuhan keperawatan sesuai dengan tahapan-tahapan dengan baik dan benar yang diperoleh selama masa pendidikan baik diakademik maupun dilapangan praktek.

2. Bagi Pasien

Diharapkan pasien dapat menerapkan terapi yang telah diberikan baik secara medik maupun terapi keperawatan yang telah diajarkan demi percepatan penyembuhan penyakit dengan masalah gangguan jiwa.

3. Bagi Perawat

Diharapkan dapat menerapkan komunikasi terapeutik dalam pelaksanaan strategi pertemuan 1-4 pada klien dengan harga diri rendah kronik sehingga dapat mempercepat proses pemulihan klien.

4. Bagi keluarga 
Agar keluarga selalu memberikan motivasi kepada klien dan juga perawatan harga diri rendah kronik pendengaran dirumah.

5. Bagi Institusi Pendidikan

Dapat meningkatkan bimbingan klinik kepada mahasiswa profesi ners sehingga mahasiswa semakin mampu dalam melakukan asuhan keperawatan pada pasienpasien yang mengalami harga diri rendah kronik.

6. Bagi Rumah Sakit

Laporan ini diharapkan dapat menjadai acuan dan referensi dalam memberikan asuhan keperawatan pada klien dengan harga diri rendah kronik. 


\section{DAFTAR PUSTAKA}

1. Andri, J., Febriawati, H., Panzilion, P., Sari, S. N., \& Utama, D. A. (2019). Implementasi keperawatan dengan pengendalian diri klien halusinasi pada klien skizofrenia. Jurnal Kesmas Asclepius, 1(2), 146-155 https://doi.org/10.31539/jka.v1i2.922

2. Atmojo, B. S. R., \& Purbaningrum, M. A. (2021). Literature Review: Penerapan Latihan Kemampuan Positif Terhadap Peningkatan Harga Diri Rendah Pada Klien Yang Mengalami Skizofrenia Dengan Gangguan Konsep Diri Harga Diri Rendah. Nursing Science Journal (NSJ), 2(1), 55-62.

3. Diana Putri, K. R. I. S. M. O. N. I. T. A. (2020). Asuhan Keperawatan Pada Klien Skizofrenia Dengan Masalah Keperawatan Harga Diri Rendah Kronis Di Rumah Sakit Jiwa Dr. Arif Zainudin Surakarta (Doctoral Dissertation, Universitas Muhammadiyah Ponorogo).

4. Dwi Saptina, C. H. A. N. D. R. A. (2020). Asuhan Keperawatan Pada Klien Skizofrenia Dengan Masalah Harga Diri Rendah Kronik (Doctoral Dissertation, Universitas Muhammadiyah Ponorogo).

5. Fajarani, A. S. (2017). Tingkat stres dan harga diri narapidana wanita di lembaga pemasyarakatan kelas II A Kota Bogor. Jurnal Riset Kesehatan Poltekkes Depkes Bandung, 9(2), 26-33.

6. Febrina. (2018). "Asuhan Keperawatan Jiwa Pada Keluarga Dengan Harga Diri Rendah Kronis di Wilayah Kerja Puskesmas Nanggalo Kota Padang” Poltekkes Kemenkes Padang, xi + 63 halaman.

7. Irawati, K., Daulima, N. H. C., \& Wardhani, I. Y. (2019). Manajemen Kasus Pada Klien Harga Diri Rendah Kronis Dengan Pendekatan Teori Caring. Jurnal Keperawatan, 11(2), 125-134.

8. https://doi.org/10.32583/keperawatan.v11i2.486

9. Keliat, Budi Anna, dkk. 2020. Asuhan Keperawatan Jiwa. Jakarta: EGC

10. Manao, B. M., \& Pardede, J. A. (2019). Correlation of Family Burden of The Prevention of Recurrence of Schizophrenia Patients. Mental Health, 4(1), 31-42.

11. Pardede, J. A., \& Hasibuan, E. K. (2019). Dukungan Caregiver Dengan Frekuensi Kekambuhan Klien Skizofrenia. Idea Nursing Journal, 10(2).

12. Pardede, J. A., \& Laia, B. (2020). Decreasing Symptoms of Risk of Violent Behavior in Schizophrenia Patients Through Group Activity Therapy. Jurnal Ilmu Keperawatan Jiwa, 3(3), 291-300. http://dx.doi.org/10.32584/jikj.v3i3.621

13. Pardede, J. A., Harjuliska, H., \& Ramadia, A. (2021). Self-Efficacy dan Peran Keluarga Berhubungan dengan Frekuensi Kekambuhan Klien Skizofrenia. Jurnal Ilmu Keperawatan Jiwa, 4(1), 57-66. http://dx.doi.org/10.32584/jikj.v4i1.846 
14. Pardede, J. A. (2019). Health Education Of Drinking Medication Adherence On Schizophrenia Patients. Journal Of Psychiatry, 2(2), 723.

15. Pardede, J. A., Keliat, B. A., \& Yulia, I. (2015). Kepatuhan Dan Komitmen Klien Skizofrenia Meningkat Setelah Diberikan Acceptance And Commitment Therapy Dan Pendidikan Kesehatan Kepatuhan Minum Obat. Jurnal Keperawatan Indonesia, 18(3), 157-166. https://doi.org/10.7454/jki.v18i3.419

16. Pardede, J. A. (2022). Koping Keluarga Tidak Efektif Dengan Pendekatan Terapi Spesialis Keperawatan Jiwa.

17. Pardede, J. A. (2013). Pendidikan Kesehatan Kepatuhan Minum Obat Pada Pasien Skizofrenia Di Kecamatan Medan Helvetia. Jurnal Pengmas Mutiara Ners 1 (1)

18. Pardede, J. A., \& Purba, J. M. (2020). Family Support Related to Quality of Life on Schizophrenia Patients. Jurnal Ilmiah Permas: Jurnal Ilmiah STIKES Kendal, 10(4), 645654.

19. Purwasih, R., \& Susilowati, Y. (2016). Penatalaksanaan Klien Gangguan Jiwa Dengan Gangguan Konsep Diri: Harga Diri Rendah Di Ruang Gathotkoco Rsjd Dr. Amino Gondohutomo Semarang. Jurnal Profesi Keperawatan (JPK), 3(2).

20. Rahayu, S., Mustikasari, M., \& Daulima, N. H. (2019). Perubahan Tanda Gejala dan Kemampuan Klien Harga Diri Rendah Kronis Setelah Latihan Terapi Kognitif dan Psikoedukasi Keluarga. Journal Educational Of Nursing (JEN), 2(1), 39-51. https://doi.org/10.37430/jen.v2i1.10

21. Rahmawati, A. N., Ramadhani, A. S., \& Apriliyani, I. (2021). Studi Kasus Harga Diri Rendah Kronis Pada Klien Skizofrenia. Jurnal Keperawatan Notokusumo, 9(2), 13-23.

22. Rahmawati, E. D. (2019). Asuhan Keperawatan Pada Klien Skizofrenia Residual Dengan Masalah Harga Diri Rendah Kronik Di Rumah Sakit Jiwa Daerah Dr. Arif Zainudin Surakarta (Doctoral Dissertation, Universitas Muhammadiyah Ponorogo).

23. Riset Kesehatan Dasar (RISKESDAS). (2018). Kementrian Kesehatan Badan Penelitian dan Pengembangan Kesehatan

24. Rokhimmah, Y., \& Rahayu, D. A. (2020). Penurunan Harga Diri Rendah Dengan Menggunakan Penerapan Terapi Okupasi (Berkebun). Ners Muda, 1(1), 18-22. Https://Doi.Org/10.26714/Nm.V1i1.5493

25. Safitri, A. (2020). Studi Literatur: Asuhan Keperawatan Keluarga Penderita Skizofrenia Dengan Gangguan Konsep Diri: Harga Diri Rendah Kronis (Doctoral dissertation, Universitas Muhammadiyah Ponorogo).

26. Sitorus, C. (2019). Pengkajian Klasifikasi Data Dalam Proses Keperawatan. 10.31219/osf.io/ksdca

27. Stuart, G. W. (2016). Prinsip dan Praktek Keperawatan Kesehatan Jiwa Stuart. 1 Indonesia Edition, by Budi Anna Keliat and Jesika Pasaribu. Singapore: Elsevier. 
28. Tuasikal, H., Siauta, M., \& Embuai, S. (2019). Upaya Peningkatan Harga Diri Rendah Dengan Terapi Aktivitas Kelompok (Stimulasi Persepsi) di Ruang Asoka (Sub Akut Laki) RSKD Provinsi Maluku. Window of Health: Jurnal Kesehatan, 345-351.

29. WHO. (2019). Mental Disorders. https://www.who.int/news-room/factsheets/detail/mental-disorders.

30. WHO, (2022\}. Schizophrenia. https://www.who.int/news-room/factsheets/detail/schizophrenia

31. Widianti, E., Keliat, B. A., \& Wardhani, I. Y. (2017). Aplikasi Terapi Spesialis Keperawatan Jiwa pada Klien Skizofrenia dengan Harga Diri Rendah Kronis di RSMM Jawa Barat. Jurnal Pendidikan Keperawatan Indonesia, 3(1), 8399.https://doi.org/10.17509/jpki.v3i1.7489.

32. Wijayati, F., Nasir, T., Hadi, I., \& Akhmad, A. (2020). Faktor-faktor yang berhubungan dengan kejadian harga diri rendah klien gangguan jiwa. Health Information: Jurnal Penelitian, 12(2), 224-235. https://doi.org/10.36990/hijp.v12i2.234 